\title{
Early, intensive marine resource exploitation by Middle Stone Age humans at Ysterfontein 1 rockshelter, South Africa
}

\author{
Elizabeth M. Niespolo ${ }^{a, b, 1,2} \oplus$, Warren D. Sharp ${ }^{b} \oplus$, Graham Avery ${ }^{\mathrm{c}}\left(\right.$, and Todd E. Dawson $^{d}$ \\ ${ }^{a}$ Department of Earth and Planetary Science, University of California, Berkeley, CA 94720; ${ }^{b}$ Berkeley Geochronology Center, Berkeley, CA 94709; \\ 'Department of Natural History, Iziko Museums of South Africa, Cape Town 8001, South Africa; and ${ }^{\mathrm{d} D e p a r t m e n t}$ of Integrative Biology, University of
} California, Berkeley, CA 94720

Edited by Marilyn L. Fogel, University of California, Riverside, CA, and approved February 26, 2021 (received for review September 24, 2020)

Modern human behavioral innovations from the Middle Stone Age (MSA) include the earliest indicators of full coastal adaptation evidenced by shell middens, yet many MSA middens remain poorly dated. We apply ${ }^{230} \mathrm{Th} / \mathrm{U}$ burial dating to ostrich eggshells (OES) from Ysterfontein 1 (YFT1, Western Cape, South Africa), a stratified MSA shell midden. ${ }^{230} \mathrm{Th} / \mathrm{U}$ burial ages of YFT1 OES are relatively precise (median $\pm 2.7 \%$ ), consistent with other age constraints, and preserve stratigraphic principles. Bayesian age-depth modeling indicates YFT1 was deposited between 119.9 to 113.1 thousand years ago $(\mathrm{ka})(95 \% \mathrm{Cl}$ of model ages), and the entire $3.8 \mathrm{~m}$ thick midden may have accumulated within $\sim 2,300$ y. Stable carbon, nitrogen, and oxygen isotopes of OES indicate that during occupation the local environment was dominated by $C_{3}$ vegetation and was initially significantly wetter than at present but became drier and cooler with time. Integrating archaeological evidence with OES ${ }^{230} \mathrm{Th} / \mathrm{U}$ ages and stable isotopes shows the following: 1) YFT1 is the oldest shell midden known, providing minimum constraints on full coastal adaptation by $\sim 120 \mathrm{ka} ; 2$ ) despite rapid sea-level drop and other climatic changes during occupation, relative shellfish proportions and sizes remain similar, suggesting adaptive foraging along a changing coastline; 3) the YFT1 lithic technocomplex is similar to other west coast assemblages but distinct from potentially synchronous industries along the southern African coast, suggesting human populations were fragmented between seasonal rainfall zones; and 4) accumulation rates (up to $1.8 \mathrm{~m} / \mathrm{ka}$ ) are much higher than previously observed for dated, stratified MSA middens, implying more intense site occupation akin to Later Stone Age middens.

geochronology | Middle Stone Age | Southern Africa | shell middens | stable isotopes

T he Middle Stone Age (MSA) defines an interval in which many "modern" human behaviors emerged, including the first indications of artistic and symbolic expression, the use of personal adornments, advancements in tool making, effective hunting of large mammal game, and the exploitation of harsher environments (e.g., refs. 1-3). The earliest records of humans intensely and systematically exploiting marine resources also derive from MSA sites (4), and archaeological sequences rich in marine shellfish remains provide insight into several key aspects of human behavioral and cultural evolution during the MSA. For example, marine foods such as shellfish and marine mammals (scavenged or hunted) have been proposed as uniquely rich sources of key nutrients promoting brain development and perhaps leading to enhanced cognitive development and higher reproductive fitness (5-8). Some workers have suggested that adaptation to systematic coastal foraging with its rich, geographically stable and predictable resources may have promoted behaviors considered to be unique and potent adaptations of Homo sapiens such as territoriality, intergroup competition, and high levels of nonkin cooperation (9). Differences in marine shell sizes and accumulation rates between MSA and Later Stone Age (LSA) coastal sequences have been interpreted to provide insight into, respectively, relative population size and intensity of site occupation through time $(10,11)$. Compared to LSA people representing comparably larger populations, smaller populations of MSA people are thought to have exploited coastal resources less intensively, more selectively, or both (4). However, without robust chronological frameworks at MSA sites, lithic technologies and evidence of behavioral innovations cannot be confidently compared between sites. We show that precise geochronology and refined paleoenvironmental information can shed light on human behavioral development, adaptations, and population sizes in the MSA.

MSA shell middens occur on the South African coastline (Fig. 1) (10, 12-21), and their ages are constrained largely by diverse techniques with precision typically of the order $\sim 10 \%$ or more at $2 \sigma$ relative uncertainty (22). Here, we apply a recently developed approach to uranium-series (hereafter U-series, or ${ }^{230} \mathrm{Th} / \mathrm{U}$ ) dating of ostrich eggshells (OES) at Ysterfontein 1 (YFT1), a well-stratified, carefully excavated MSA shell midden on the west coast of the Western Cape Province, South Africa, hosting a record of early shellfishing $(10,12,13)$.

Unlike other U-series dating of OES, “230 $\mathrm{Th} / \mathrm{U}$ burial dating” accounts for the secondary uptake of U in OES from soil pore water upon burial and uses geochemical criteria inherent to the

\section{Significance}

Novel ${ }^{230} \mathrm{Th} / \mathrm{U}$ burial dating of ostrich eggshells complements other dating methods applicable to archaeological materials beyond the range of radiocarbon dating. New ages for the Ysterfontein 1 (YFT1) shell midden show it accumulated rapidly between $\sim 120$ to 113 ka closely following the Last Interglacial sea-level highstand. The ages show the great antiquity of intensive human coastal adaptation, date a distinctive lithic industry, and show that teeth from YFT1 are among the oldest $H$. sapiens fossils recovered in southern Africa. Stable isotopes of ostrich eggshells indicate rapid cooling and drying during site occupation. Despite rapid sea-level drop and increasing aridity, the site's occupants maintained a consistent diet, which may not indicate a stable paleoenvironment but rather results from systematic, selective foraging.

Author contributions: E.M.N. and W.D.S. designed research; E.M.N. and W.D.S. performed research; E.M.N. and W.D.S. contributed new reagents/analytic tools; G.A. excavated and procured samples; E.M.N., W.D.S., G.A., and T.E.D. analyzed data; and E.M.N., W.D.S., and G.A. wrote the paper.

The authors declare no competing interest.

This article is a PNAS Direct Submission.

Published under the PNAS license.

${ }^{1}$ Present address: Division of Geological and Planetary Sciences, California Institute of Technology, Pasadena, CA 91125.

${ }^{2}$ To whom correspondence may be addressed. Email: niespolo@caltech.edu.

This article contains supporting information online at https://www.pnas.org/lookup/suppl/ doi:10.1073/pnas.2020042118/-/DCSupplemental.

Published April 12, 2021. 

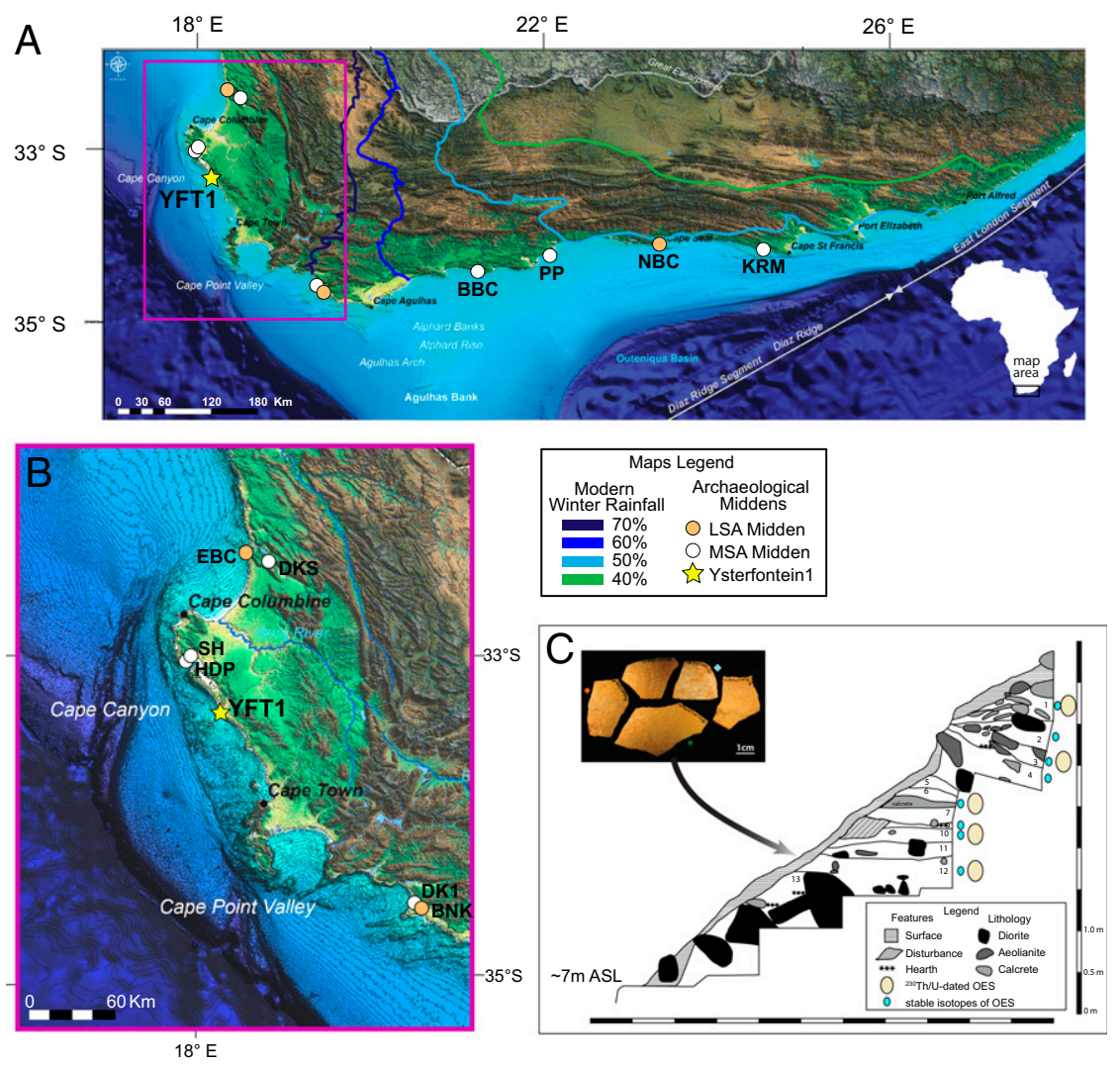

Fig. 1. YFT1 site location, locations of other sites with marine shell-rich layers, and YFT1 site stratigraphy. ( $A$ ) Distribution of shell middens along the coasts of South Africa, with modern winter seasonal rainfall isopleths; $(B$, Inset) detailed map ( $A$, pink outline) of shell middens on the western coast in the winter rainfall zone. Maps in $A$ and $B$ are modified from ref. 83. (C) YFT1 composite stratigraphy, numbered LG, and placement of OES dated by ${ }^{230}$ Th/U burial dating and/or with stable isotope data, after ref. 12; Inset are the OES sampled from LG12 for stable isotopes and ${ }^{230}$ Th/U burial dating. Site acronyms for maps $A$ and $B$ are as follows: BBC, Blombos Cave; BNK, Byneskranskop Cave; DK1, Die Kelders 1; DKS, Diepkloof Shelter; EBC, Elands Bay Cave; HDP, Hoedjiespunt; KRM, Klasies River Mouth; NBC, Nelson Bay Cave; PP, Pinnacle Point; SH, Sea Harvest; and YFT1, Ysterfontein 1.

${ }^{230} \mathrm{Th} / \mathrm{U}$ data to help identify reliable ages (23-27). The method was first tested against radiocarbon $\left({ }^{14} \mathrm{C}\right)$ dating in LSA contexts (23), and this paper describes results from an extension of the method into archaeological contexts beyond the range of ${ }^{14} \mathrm{C}$ dating ( $\sim 50$ thousand years ago; hereafter, ka), which has not been previously attempted. Light stable isotope-paleoenvironmental proxies from OES also provide paleoenvironmental context directly related to the archaeological site (28-31), which we apply to OES recovered from YFT1. OES fragments at YFT1 are interspersed throughout the $3.8 \mathrm{~m}$ stratified sequence (SI Appendix), providing abundant sample material for dating. The chronological framework and paleoenvironmental context for YFT1 presented here provides key implications for the spatiotemporal coherence of South African lithic technologies and early evidence of intensive shellfishing, a coastal adaptation thus far considered unique to modern humans (9).

\section{YFT1, an MSA Example of Coastal Adaptation}

YFT1 (3320'51" S, $\left.18^{\circ} 09^{\prime} 05^{\prime \prime} \mathrm{E}\right)$, a collapsed coastal rock shelter with a base $\sim 7 \mathrm{~m}$ above modern sea level (mRSL), hosts an MSA deposit rich in lithic artifacts and faunal remains (Fig. 1 and SI Appendix). YFT1 is particularly notable for its especially large and fully analyzed faunal assemblage, including the shellfish sample totaling $139.25 \mathrm{~kg}$ and a minimum number of individuals $=10,337$ $(10,12)$. The stratified deposit was excavated in 13 distinct sedimentary layer groups (LG) of varying thickness. LG 13 at the base of the shelter is reworked from storm surges likely occurring during the Last Interglacial (LIG) sea-level highstand 127 to $120 \mathrm{ka}$
$(12,32-34)$, but it includes anthropogenic materials. LG 12 through LG 6 are densely packed, clast-supported deposits with a carbonatesand matrix (calcarenites). Clasts in those LGs comprise disarticulated intertidal gastropods, bivalves, terrestrial faunal remains, and stone tools (12) - anthropogenically analogous to a bedded rudstone $(35,36)$ and considered to be a fully developed shell midden of almost entirely anthropogenic input. Evidence from LG 5 though LG 3 indicates a transition from human occupation to visitation by humans and possibly brown hyenas (Hyaena brunnea) in LG 3, and upper LG 1 and LG 2 indicate less-intensive human visits including evidence of hyenas as agents of accumulation. In addition to hosting abundant faunal remains, including marine invertebrate and terrestrial vertebrate shells (tortoise), terrestrial faunal bones, and OES $(10,12)$, YFT1 presents a unique MSA technocomplex of over 7,000 lithic artifacts, including red ochre and manganese used as pigments, denticulate points, but lacking backed pieces (blades with one edge blunted by removal of tiny flakes), and bifacial points (SI Appendix) (37). Altogether, YFT1 presents evidence of coastal adaptation in the MSA defined as systematic, recurrent use of coastal resources and subsistence dependent on the sea (e.g., ref. 9). Marine-invertebrate assemblages suggest intertidal cool-to-cold water temperatures consistent with local modern intertidal conditions, while the additional presence of the warmer water-adapted brown mussel (Perna perna) suggests some local warm water (12). Three isolated human teeth have been recovered at YFT1 (38): a permanent lower-right third molar (M3) from LG 4, a permanent upper-lateral incisor (I2) from LG 5, and a deciduous upper-central incisor (I1) from LG 13 (SI Appendix). 
Like many MSA contexts, YFT1 hosts abundant OES fragments. The eggs served as a food source for MSA people and were accumulated here as debris from humans and other carnivores. Eggshells also provided material for artifacts such as beads used for personal adornment and perforated, engraved eggshells that may have served as water vessels $(18,39-41)$, although such evidence is not present at YFT1. Until now, YFT1 had only broad and somewhat contradictory age constraints indicating the deposit was between $\sim 140$ and $46 \mathrm{ka}(10,12)$. However, the shelter floor stands at $7 \mathrm{~m}$ above sea level (Fig. 1), and storm surges during the LIG sea-level highstands of 5 to $8 \mathrm{~m}$ above relative sea level

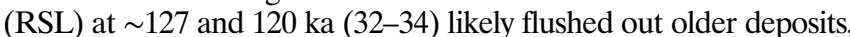
as corroborated by the presence of storm-surge deposits at the shelter base in LG 13 (12). Hence, prior chronological constraints would place the remaining YFT1 MSA deposits broadly between $\sim 120$ to $46 \mathrm{ka}$. More precise ages for the YFT1 sequence allow the constraints on MSA populations and site occupancy afforded by the site and the site's distinctive lithic technocomplex to be placed in the context of other well-studied MSA sites in South Africa and elsewhere. ${ }^{230} \mathrm{Th} / \mathrm{U}$ burial ages of OES fragments presented here provide much more precise ages, and with these we produce a Bayesian age-depth model to anchor the associated archaeological materials and stable-isotope paleoenvironmental proxy data in time.

\section{${ }^{230} \mathrm{Th} / \mathrm{U}$ Burial Dating and Paired Stable-Isotope Analyses of OES}

In Africa and newly populated territories across the Earth, humans utilized large avian eggs for food and their shells for personal uses (e.g., tools, beads, and containers), so eggshells are frequently found in prehistoric archaeological contexts (e.g., refs. 42 and 43). OES consist of $\sim 2 \mathrm{~mm}$ thick, low-Mg calcite containing 1 to 3 wt. $\%$ organics and are suitable for ${ }^{230} \mathrm{Th} / \mathrm{U}$ dating, a technique capable of producing accurate, precise ages $(\sim 0.1 \%$, $2 \sigma$ ) with a useful limit of $>500$ ka (e.g., refs. 22 and 44). Similar to other biominerals of higher animals, eggshells contain little to no primary $\mathrm{U}$; accordingly, $\mathrm{U}$ in ancient OES is secondary. Until recently, U-series dating of eggshells has been carried out without consideration of the effects of prolonged secondary uptake of U. In contrast, " $230 \mathrm{Th} / \mathrm{U}$ burial dating” of OES, which we employ herein, explicitly accounts for U uptake by OES from soil water after burial. In a previous study, we documented U uptake patterns in archaeological OES, showed that the effects of prolonged $U$ uptake could be mitigated by applying a simple diffusion model to ages measured on OES subsamples, and demonstrated that resulting model ages termed ${ }^{230} \mathrm{Th} / \mathrm{U}$ burial ages were concordant with ${ }^{14} \mathrm{C}$ ages measured on splits of several latest Pleistocene to Holocene eggshells $(23) .{ }^{230} \mathrm{Th} / \mathrm{U}$ burial dating provides internal reliability criteria inherent to the U-series data, typically yields relatively precise ages (circa \pm 1 to $3 \%, 2 \sigma$ ) compared to trapped-charge techniques (e.g., luminescence and electron spin resonance dating), and may be applied to archival samples because unlike the latter techniques ${ }^{230} \mathrm{Th} / \mathrm{U}$ dating does not require in situ radiation measurements. Such attributes make ${ }^{230} \mathrm{Th} / \mathrm{U}$ burial dating of OES a promising technique for precisely dating Middle to Late Pleistocene paleoanthropological sequences beyond the ${ }^{14} \mathrm{C}$ limit, as we show herein.

YFT1 hosts abundant OES ( $\sim 0.1$ to $4 \mathrm{~kg}$ per layer) allowing for careful and systematic sample selection throughout the sequence. Each OES fragment sampled in this study was at least $\sim 2 \times 2 \mathrm{~cm}$, making them unlikely to be susceptible to vertical mixing (SI Appendix). A total of 17 OES fragments from five stratigraphic layers of the YFT sequence (LG 1, 3, 6, 10, and 12; Fig. 1 and SI Appendix) were selected to compare in-situ concentrations and distributions of ${ }^{238} \mathrm{U}$ and ${ }^{232} \mathrm{Th}$ in samples using laser ablation inductively coupled plasma mass spectrometry (LA-ICP-MS). OES fragments selected for ${ }^{230} \mathrm{Th} / \mathrm{U}$ dating were analyzed by solution mode on the same ICP-MS. Previous work defined geochemical reliability criteria used in the ${ }^{230} \mathrm{Th} / \mathrm{U}$ burial dating approach, which were assessed in a "blind test" that compared ${ }^{230} \mathrm{Th} / \mathrm{U}$ burial ages for OES with precise ${ }^{14} \mathrm{C}$ ages on splits of the same eggshells (23). In addition to these geochemical criteria, we assess the fidelity of our ${ }^{230} \mathrm{Th} / \mathrm{U}$ burial ages beyond the ${ }^{14} \mathrm{C}$ limit at YFT1 using stratigraphic principles, namely the reproducibility of ages within single layers, the preservation of stratigraphic order, and the prior sea-level basal constraint.

In addition, the carbon $(\mathrm{C})$, oxygen $(\mathrm{O})$, and nitrogen $(\mathrm{N})$ stable-isotope compositions of OES provide proxy records for, respectively, past diet (related to local vegetation), evapotranspiration (related to temperature and relative humidity), and precipitation amount (28-30). A total of 47 OES fragments were selected for $\mathrm{C}$ and $\mathrm{O}$ stable-isotope analyses of the carbonate fraction (calcite), including all 13 dated samples. Organic $\mathrm{C}$ and $\mathrm{N}$ stable isotopes from the total organic fraction (TOF) were analyzed from 40 of 47 samples, including 5 of the dated samples. These proxy records reveal the paleoenvironmental context in which shellfishing and foraging at YFT1 took place. By anchoring the proxy records to our Bayesian age model, we examine the pace of environmental changes at the site.

\section{Results}

LA and Subsampling OES Suitable for ${ }^{230} \mathrm{Th} / \mathrm{U}$ Burial Dating. LA results reveal patterns of ${ }^{238} \mathrm{U}$ and ${ }^{232} \mathrm{Th}$ (hereafter, concentrations are denoted by square brackets) that guide selection of optimal OES and sampling positions for dating (23). LA profiles across eggshells demonstrate similar patterns of secondary $[\mathrm{U}]$ in most samples that vary with eggshell structures (Fig. 2) (23-25). In palisade crystals (macroscopic columnar calcite crystal bundles internal to the OES surfaces), [U] ranges from $\sim 13$ to $160 \mathrm{ppb}$ $($ median $=33.6 \mathrm{ppb})$, and $[\mathrm{U}]$ profiles are flattest, indicating fast uptake of U (SI Appendix). Similar [U] profiles are observed in eggshell fragments that yield ${ }^{14} \mathrm{C}$ and ${ }^{230} \mathrm{Th} / \mathrm{U}$ burial ages in good agreement (23). $U$ in OES from the same layers also imply an environmental control on [U]. At YFT1, palisade-layer [U] values are more similar among OES from the same layer than they are between OES from different layers. This suggests that [U] is controlled by soil pore water $U$ availability, which may vary depending on the matrix composition and/or its permeability.

LA ${ }^{232}$ Th profiles help identify detritus-rich areas with high common $\mathrm{Th}$, which require larger detrital ${ }^{230} \mathrm{Th}$ corrections that negatively impact ${ }^{230} \mathrm{Th} / \mathrm{U}$ ages. ${ }^{232} \mathrm{Th} /{ }^{238} \mathrm{U}$ ratios are lowest away from OES surfaces in the palisade crystals (range $\sim 0.0005$ to 0.01 ; Fig. 2) and are highest at the inner and outer crystal layers where the eggshell is in contact with silicate detritus incorporated during burial. All YFT1 samples have sufficiently low ${ }^{232} \mathrm{Th} /{ }^{238} \mathrm{U}$ in the palisades (i.e., $<<0.1$ ) so that model corrections for detritus are relatively small (see Table 1 to compare detritus-corrected and detritus-uncorrected ages). Because the palisade crystals show both fast uptake of U (SI Appendix, Fig. S6) and low ${ }^{232} \mathrm{Th} /{ }^{238} \mathrm{U}$ ratios (indicating minimal detrital contamination), this part of the eggshell is optimal for U-series measurements. In addition to removing exterior OES surfaces by mechanical abrasion, we drill out large macroscopic pores that cross cut the palisade crystals that originally provided air pathways for incubating chicks to breathe. Previous LA results have shown the pores provide vugs in which secondary precipitates may form as well as entraining Th-rich detritus $(23,25)$. Recent work comparing dated OES with and without removing pore infill showed systematically younger ages if this material was not removed (45).

For ${ }^{230} \mathrm{Th} / \mathrm{U}$ dating, we prepared surface-parallel tablets $\sim 0.5 \mathrm{~mm}$ thick from two positions located in the outer and inner palisade layer of each dated OES via selective abrasion. Of the 17 OES analyzed by LA, 13 were selected for dating, and their $U$ and Th isotope ratios were measured via solution analyses on a Thermo Fischer Neptune Plus ICP-MS (Table 1). All ratios given in parentheses are activity ratios. Solution analyses corroborate the 

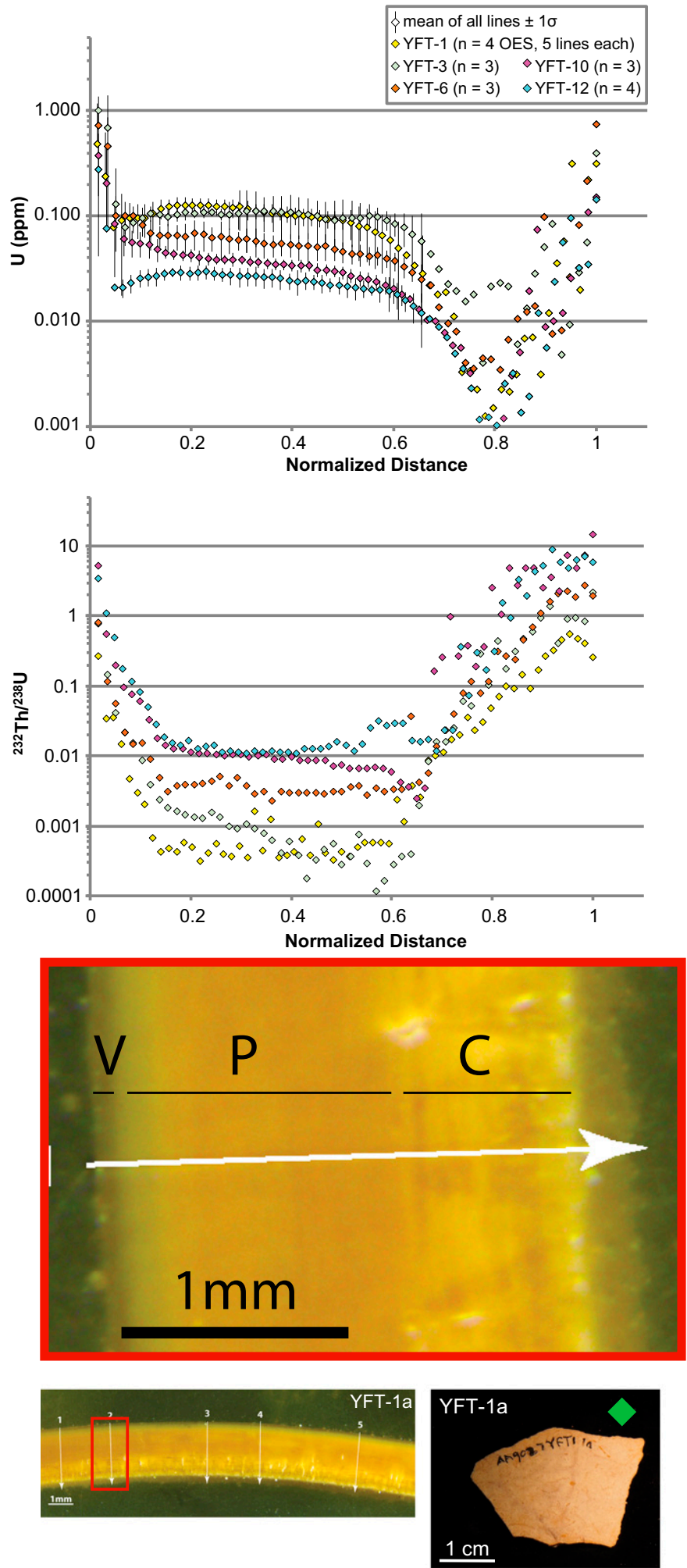

Fig. 2. (Top) Mean $\left[{ }^{238} \mathrm{U}\right]$ and ${ }^{232} \mathrm{Th} /{ }^{238} \mathrm{U}$ ratios (Middle) from LA ICP-MS for 17 eggshells from YFT1 magnified image of the radial cross-section of one eggshell polished in an epoxy mount (Bottom), showing the structural transitions in the eggshell corresponding with changes in $\mathrm{U}$ and Th concentrations. Abbreviations for structural changes in the red inset image are as follows: V, vertical crystal layer; P, palisade layer; and C, cone layer. Location of the inset image is shown in the red box in the image of the polished eggshell mount (Lower Left); (Lower Right) original eggshell fragment before sample preparations, from LG 1 at YFT1. For all individual LA profiles and sample images, reference SI Appendix. range of $[\mathrm{U}]$ determined by $\mathrm{LA}$, and $\left({ }^{230} \mathrm{Th} /{ }^{232} \mathrm{Th}\right)$ ratios range from $\sim 39$ to 3,334 (median $=256.2, n=26)$, consistent with very little detrital contamination with minor to negligible impact on final ages and their errors (Table 1). For a detailed explanation of the $\left({ }^{230} \mathrm{Th} /{ }^{232} \mathrm{Th}\right)$ model correction, see ref. 48 .

${ }^{230} \mathrm{Th} / \mathrm{U}$ Burial Ages and the Age of YFT1. ${ }^{230} \mathrm{Th} / \mathrm{U}$ burial ages are presented with $2 \sigma$ uncertainties (Table 1). Individual ${ }^{230} \mathrm{Th} / \mathrm{U}$ ages range from 109.6 to $118.2 \mathrm{ka}$ and have uncertainties between $0.8 \%$ and $3.4 \%$ (median $=1.6 \%$ or $1.8 \mathrm{ka}$ ). To most closely approximate the time of burial, we model the time that $\mathrm{U}$ was first taken up by the eggshell fragment at its outer surface. For each OES, two prepared subsamples are dated that derive from known distances from the eggshell's outer surface, where U uptake begins. Plotting the resulting ages as a function of their normalized distance squared causes the relationship between age and distance from the outer surface to become mathematically linear (49). Extrapolating the age-distance trend defined by the two subsamples to the outer surface of the eggshell models the time when $U$ was first taken up upon burial (23). Because $U$ enters from the outer surface, where the eggshell is also contaminated by detrital ${ }^{232}$ Th (Fig. 2), this extrapolated age, defined as the " ${ }^{630} \mathrm{Th} / \mathrm{U}$ burial age," allows us to 1) determine U-series ages on "clean" (detritus-poor) subsamples, 2) account for prolonged $U$ uptake, and 3) estimate the time that $U$ was first taken up at the eggshell's outer surface upon burial.

${ }^{230} \mathrm{Th} / \mathrm{U}$ burial ages determined in this study have relative $2 \sigma$ precisions of 0.7 to $5.6 \%$ (median $=2.7 \%, 3.1 \mathrm{ka}$ ). Of the 13 OES fragments, 11 yielded U-series ages whose outer-shell age $\geq$ inner-shell age (within $1 \sigma$ ), as is expected for closed-system, single-stage uptake of $U$ from the outer surface (23). In 10 of 11 eggshells meeting the criteria for burial ages, calculated initial ${ }^{234} U /{ }^{238} U$ activity ratios (hereafter, $\left({ }^{234} U /{ }^{238} U\right)_{0}$ ) of outer and inner shells agree within analytical uncertainties (Table 1). Since ${ }^{234} \mathrm{U} /{ }^{238} \mathrm{U}$ ratios of soil pore waters vary with time (e.g., ref. 23 ), the uniform $U$ ratios of the eggshells are consistent with relatively rapid uptake of $U$ followed by closed evolution of the $\mathrm{U}-\mathrm{Th}$ system. We calculate ${ }^{230} \mathrm{Th} / \mathrm{U}$ burial ages for eggshells with outer-shell ages $>$ inner-shell ages (nine samples) using a one-dimensional single-stage diffusive uptake model. For eggshells whose outer- and inner-shell ages are indistinguishable at $1 \sigma$ precision (two samples), we calculate ${ }^{230} \mathrm{Th} / \mathrm{U}$ burial ages using a weighted mean of their outer- and inner-shell ages (Fig. 3 and SI Appendix). ${ }^{230} \mathrm{Th} / \mathrm{U}$ burial ages range from 110.2 to 118.2 ka (Table 1). Two further eggshells have inner-shell ages that exceed their outer-shell ages beyond their $1 \sigma$ errors. Such relations are inconsistent with single-stage U uptake across the outer surface of the shell, and we interpret them to provide only minimum age estimates.

In LGs with multiple dated eggshells, ${ }^{230} \mathrm{Th} / \mathrm{U}$ burial ages generally cluster (e.g., LGs 1, 6, and 10 in Fig. 3). An exception to this pattern occurs in layer 12 , where the youngest ${ }^{230} \mathrm{Th} / \mathrm{U}$ burial age (YFT-12F, 110.2 $\pm 3.3 \mathrm{ka}$ ) is distinct outside of uncertainties from two out of three other ages. If included, the youngest age causes ages from LG 12 to scatter more than expected from their uncertainties alone as indicated by a mean square of weighted deviates $(\mathrm{MSWD})=3.7$ and $P$ value $=0.012$, for the four ${ }^{230} \mathrm{Th} / \mathrm{U}$ burial ages from LG 12 . Considering only the three oldest samples provides a statistically uniform age population for LG $12(\mathrm{MSWD}=0.83$ and $P=0.43)$. With the exclusion of the single outlier in LG 12 , the remaining $10^{230} \mathrm{Th} / \mathrm{U}$ burial ages are consistent with stratigraphic order within errors.

The OES ${ }^{230} \mathrm{Th} / \mathrm{U}$ burial ages are consistent with the previous broader age constraints. They are older than the overlying ${ }^{14} \mathrm{C}$ age of $>46.4 \mathrm{ka}$ and younger than the constraint that the YFT1 sequence must postdate the LIG sea-level highstand. The highstand is locally constrained by southern, coastal, intertidal zone deposits dated by optically stimulated luminescence (OSL) dating, which combined with local geology, indicate two peaks in sea 
Table 1. U-series concentrations, activity ratios, and calculated ages for YFT1 OES samples

\begin{tabular}{|c|c|c|c|c|c|c|c|c|c|c|c|c|c|}
\hline \multirow[b]{2}{*}{ Sample ID } & \multirow[b]{2}{*}{ Tablet } & \multirow[b]{2}{*}{$U(p p b)$} & \multirow[b]{2}{*}{${ }^{232} \mathrm{Th}$ (ppb) } & \multirow[b]{2}{*}{ (230Th p $\left.^{232} \mathrm{Th}\right) *$} & \multirow{2}{*}{$\begin{array}{c}\text { Initial } \\
\left.{ }^{234} \cup /^{238} \mathrm{U}\right)^{\dagger}\end{array}$} & \multirow[b]{2}{*}{$\pm(2 \sigma, a b)}$. & \multicolumn{2}{|c|}{$\begin{array}{c}\text { Uncorrected } \\
\text { age }^{\ddagger}\end{array}$} & \multicolumn{2}{|c|}{ Corrected age ${ }^{\S}$} & \multicolumn{2}{|c|}{$\begin{array}{c}{ }^{230} \mathrm{Th} / \mathrm{U} \text { burial } \\
\text { age }\end{array}$} & \multirow{2}{*}{$\begin{array}{l}\text { Included } \\
\text { age model }\end{array}$} \\
\hline & & & & & & & $k a$ & $\pm(2 \sigma), \mathrm{ka}$ & ka & $\pm(2 \sigma), \mathrm{ka}$ & $\mathrm{Ka}$ & $\pm(2 \sigma), \mathrm{ka}$ & \\
\hline \multirow[t]{2}{*}{ YFT1-1A } & Outer & 160.13 & 0.11 & $3,162.48$ & 1.0853 & 0.0039 & 115.43 & 1.96 & 115.41 & 1.96 & 116.1 & 3.4 & $\mathbf{Y}$ \\
\hline & Inner & 113.32 & 0.11 & $2,262.61$ & 1.0892 & 0.0038 & 114.34 & 1.90 & 114.31 & 1.90 & & & \\
\hline \multirow[t]{2}{*}{ YFT1-1C } & Outer & 160.06 & 0.10 & $3,333.70$ & 1.0755 & 0.0035 & 113.26 & 1.04 & 113.24 & 1.04 & 114.5 & 2.2 & $\mathbf{Y}$ \\
\hline & Inner & 115.33 & 0.11 & $2,285.56$ & 1.0754 & 0.0033 & 111.11 & 2.55 & 111.08 & 2.55 & & & \\
\hline \multirow[t]{2}{*}{ YFT1-1D } & Outer & 154.51 & 0.00 & $1,375.46$ & 1.0982 & 0.0031 & 110.46 & 1.66 & 110.42 & 1.66 & & N/A & $\mathbf{N}$ \\
\hline & Inner & 115.31 & 0.00 & $1,173.90$ & 1.1230 & 0.0036 & 115.82 & 1.43 & 115.77 & 1.44 & & & \\
\hline \multirow[t]{2}{*}{ YFT1-1E } & Outer & 69.41 & 0.00 & $1,771.95$ & 1.0884 & 0.0044 & 107.57 & 1.29 & 107.55 & 1.29 & & $\mathrm{~N} / \mathrm{A}$ & N \\
\hline & Inner & 58.78 & 0.00 & $2,307.78$ & 1.0827 & 0.0037 & 110.86 & 1.19 & 110.84 & 1.19 & & & \\
\hline \multirow[t]{2}{*}{ YFT1-3C } & Outer & 91.11 & 0.06 & $3,091.88$ & 1.0849 & 0.0038 & 113.57 & 1.11 & 113.56 & 1.11 & 114.3 & 0.9 & $Y$ \\
\hline & Inner & 58.37 & 0.07 & $1,843.26$ & 1.0899 & 0.0056 & 115.05 & 1.36 & 115.02 & 1.36 & & & \\
\hline \multirow[t]{2}{*}{ YFT1-6D } & Outer & 46.38 & 0.26 & 419.50 & 1.1860 & 0.0046 & 118.25 & 0.98 & 118.12 & 0.98 & 118.2 & 0.8 & $Y$ \\
\hline & Inner & 34.67 & 0.26 & 318.11 & 1.1961 & 0.0070 & 118.45 & 1.56 & 118.28 & 1.57 & & & \\
\hline \multirow[t]{2}{*}{ YFT1-6E } & Outer & 46.92 & 0.34 & 324.26 & 1.1753 & 0.0093 & 117.81 & 1.99 & 117.65 & 1.99 & 118.2 & 3.2 & $Y$ \\
\hline & Inner & 31.72 & 0.38 & 194.33 & 1.1945 & 0.0090 & 116.92 & 1.84 & 116.65 & 1.84 & & & \\
\hline \multirow[t]{2}{*}{ YFT1-10A } & Outer & 29.98 & 1.37 & 52.14 & 1.2342 & 0.0240 & 115.02 & 3.86 & 113.95 & 3.88 & 114.6 & 6.4 & $Y$ \\
\hline & Inner & 24.80 & 0.79 & 74.46 & 1.2411 & 0.0108 & 113.60 & 2.45 & 112.87 & 2.48 & & & \\
\hline \multirow[t]{2}{*}{ YFT1-10E } & Outer & 32.50 & 0.56 & 149.89 & 1.3697 & 0.0061 & 113.89 & 1.46 & 113.53 & 1.47 & 115.1 & 3.0 & $\mathbf{Y}$ \\
\hline & Inner & 27.37 & 0.36 & 187.21 & 1.3190 & 0.0064 & 111.97 & 1.67 & 111.69 & 1.68 & & & \\
\hline \multirow[t]{2}{*}{ YFT1-12F } & Outer & 17.39 & 0.69 & 58.93 & 1.2252 & 0.0054 & 110.93 & 2.12 & 109.99 & 2.18 & 110.2 & 3.3 & N \\
\hline & Inner & 12.59 & 0.76 & 38.46 & 1.2301 & 0.0068 & 111.10 & 1.73 & 109.65 & 1.91 & & & \\
\hline \multirow[t]{2}{*}{ YFT1-12G } & Outer & 23.32 & 0.78 & 67.73 & 1.1545 & 0.0051 & 116.33 & 1.75 & 115.48 & 1.81 & 116.9 & 3.1 & $Y$ \\
\hline & Inner & 20.23 & 0.63 & 71.82 & 1.1512 & 0.0057 & 113.93 & 1.74 & 113.14 & 1.80 & & & \\
\hline \multirow[t]{2}{*}{ YFT1-12I } & Outer & 22.52 & 0.60 & 83.82 & 1.1553 & 0.0032 & 114.08 & 1.75 & 113.40 & 1.79 & 114.5 & 2.8 & $Y$ \\
\hline & Inner & 15.66 & 0.51 & 68.31 & 1.1595 & 0.0061 & 112.10 & 1.94 & 111.28 & 2.00 & & & \\
\hline \multirow[t]{2}{*}{ YFT1-12J } & Outer & 23.38 & 0.97 & 57.49 & 1.2356 & 0.0038 & 115.75 & 1.82 & 114.76 & 1.91 & 116.7 & 3.2 & $\mathbf{Y}$ \\
\hline & Inner & 21.90 & 0.37 & 138.97 & 1.2242 & 0.0085 & 111.68 & 2.36 & 111.29 & 2.37 & & & \\
\hline
\end{tabular}

YFT1 OES naming convention: YFT1-[layer group][individual]. Reference SI Appendix for details of analytical methods and Dataset S1B for comprehensive data table.

*All isotope ratios are activity ratios.

${ }^{+}$Initial $\left({ }^{234} \mathrm{U} / 238 \mathrm{U}\right)$ is back calculated from the measured ratio and the corrected age. ${ }^{230} \mathrm{Th} / \mathrm{U}$ burial ages in italics are calculated from the weighted mean of two subsamples.

${ }^{\ddagger}$ Uncorrected ages are calculated from measured ratios. Decay constants used for all ages are those of ref. 46 for ${ }^{238} \mathrm{U}$ and ref. 47 for ${ }^{230} \mathrm{Th}$ and ${ }^{234} \mathrm{U}$.

${ }^{\S}$ Detritus-corrected ages were corrected for $U$ and ${ }^{232} \mathrm{Th}$ from detritus using $\left({ }^{232} \mathrm{Th} /{ }^{238} \mathrm{U}\right)=1.21 \pm 0.60,\left({ }^{230} \mathrm{Th} /{ }^{238} \mathrm{U}\right)=1.0 \pm 0.1$, and $\left({ }^{234} \mathrm{U} /{ }^{238} \mathrm{U}\right)=1.0 \pm 0.1$.

level (the first at $\sim 5$ to $6 \mathrm{mRSL}$, and the second between 6.3 and $7.8 \mathrm{mRSL})$ dated between $124.3 \pm 9 \mathrm{ka}$ and $111.2 \pm 7 \mathrm{ka}(1 \sigma$ errors; see refs. 32, 34 and 50). Comparing these to other more precisely dated records modeling sea level at another southern hemisphere location would indicate the second larger sea-level peak occurred $\sim 120 \mathrm{ka}(32,50)$. This second sea-level maximum, if of similar magnitude along the western coast, may have washed out the base of YFT1, as is evidenced by the storm surge deposits in $\mathrm{LG} 13$. OES ${ }^{230} \mathrm{Th} / \mathrm{U}$ burial ages skew toward the younger end of, and are slightly younger than, OSL ages determined on small, multigrain populations of quartz from LG 1, 6, 12, and 13 of $128.6 \pm 12.6,120.6 \pm 13.2,132.1 \pm 16.0$, and $127.5 \pm 17.6 \mathrm{ka}$, respectively (12). While the luminescence ages completely overlap with the interval represented by the OES ${ }^{230} \mathrm{Th} / \mathrm{U}$ burial ages, they provide a much less precise constraint, and the median age from the OSL results $(\sim 127 \mathrm{ka})$ is older than both the OES ${ }^{230} \mathrm{Th} / \mathrm{U}$ burial ages and the $\sim 120$ ka maximum sea-level highstand. Both the luminescence and ${ }^{230} \mathrm{Th} / \mathrm{U}$ burial dating techniques represent the time of burial, and they are broadly consistent with other constraints; the ${ }^{230} \mathrm{Th} / \mathrm{U}$ burial ages are much more precise and consistent with the sea-level constraint.
${ }^{230} \mathrm{Th} / \mathrm{U}$ burial ages, excluding the outlier in LG12 discussed above, were used to construct a Bayesian age model using Bchron (51-53), a Bayesian modeling package implemented in $\mathrm{R}$ (54) that assumes sediments become older with depth (Fig. 3). The Bayesian model provides a mean age-depth relation and $95 \%$ CI for the YFT1 sequence. The $95 \%$ CIs for the top and bottom of the deposit indicate the YFT shell midden was deposited between $\sim 119.9$ and $113.1 \mathrm{ka}$ (Dataset S1), consistent with geological evidence indicating that the sequence postdates the LIG sea-level highstand that terminated at $\sim 120$ ka. Mean model ages imply that the entire shell midden may have been deposited within $\sim 2,300 \mathrm{y}$, from $\sim 116.3$ to $114.0 \mathrm{ka}$. Considering the mean model ages for each LG and site stratigraphy, archaeological deposits LG 12 to LG 1 may each represent as little as $\sim 30$ to $375 \mathrm{y}$. The deepest layer (LG 13) hosts reworked archaeological material from storm surges and lacks measured ages; however, the age model brackets the maximum age of the base of LG 12 at $118.5 \mathrm{ka}$, providing a minimum for the age of the high sea level that washed out the base of the sequence.

The YFT1 model ages imply accumulation of the entire shelter deposit over $\sim 2.3$ to 6.8 ka using the mean and $95 \%$ CI of the Bayesian age model, respectively. Midden accumulation rates 


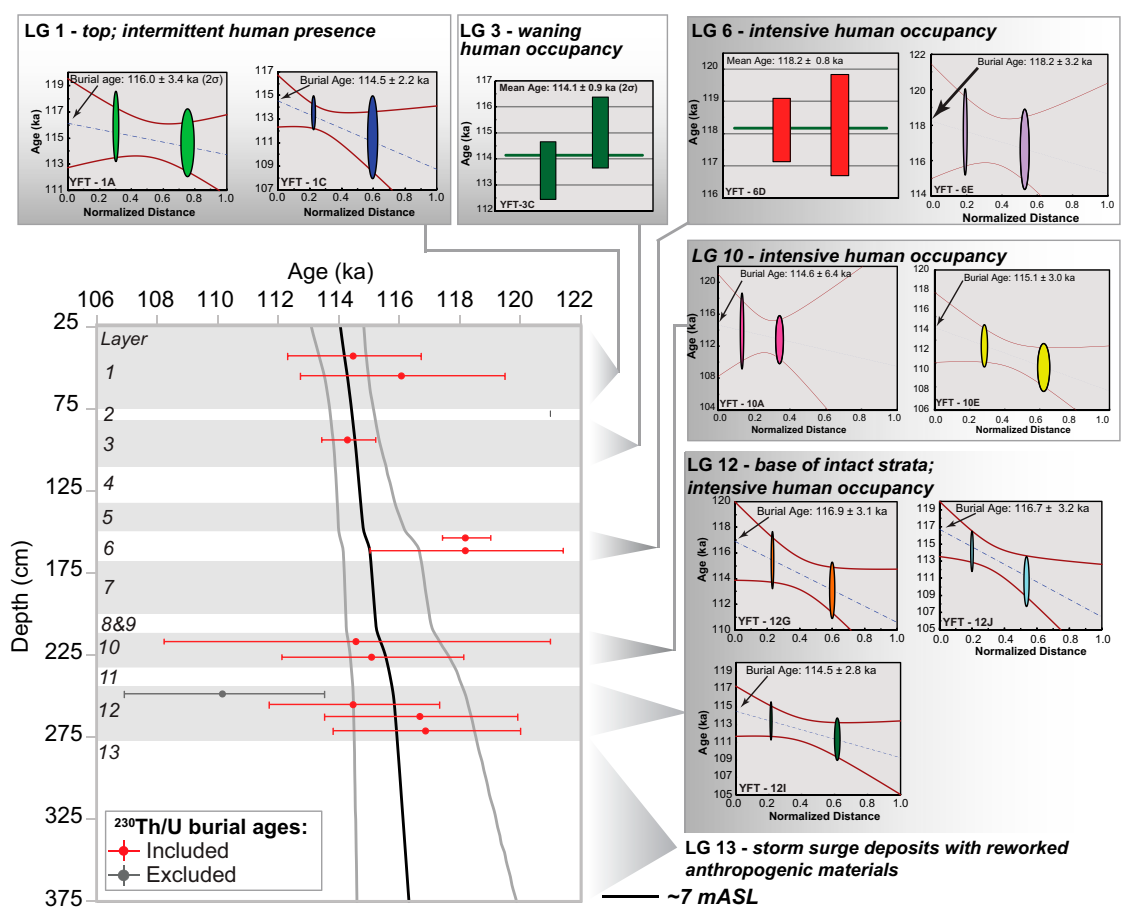

Fig. 3. ${ }^{230} \mathrm{Th} / \mathrm{U}$ burial ages with $2 \sigma$ uncertainties, plotted in stratigraphic order according to the depth and thickness of each LG and resultant Bayesian age-depth model for YFT1. ${ }^{230} \mathrm{Th} / \mathrm{U}$ burial ages of OES fragments from the same LG are reproducible, and the ages preserve stratigraphic order within uncertainties when one outlier is excluded (gray point). The median age-depth relation is shown on the model (black line) and $95 \% \mathrm{Cl}$ (gray). All sample images and burial-age plots can be found in SI Appendix.

are calculated from the deposit thickness divided by the duration of accumulation (Table 2). At YFT1, these correspond with rates of $\sim 1.7$ to $0.6 \mathrm{~m} / \mathrm{ka}$ at mean and $95 \% \mathrm{CI}$ of the age model, respectively, indicating that YFT1 accumulated far more rapidly than other shell middens of Mid to Late Pleistocene age. While it is challenging to deconvolute other depositional processes contributing at other older MSA sites, some midden layers at these sites can be assessed in comparison to YFT1. For example, the main units hosting individual midden layers at Blombos Cave (55, 56), such as unit M2 upper (hosting shell-rich layer $\mathrm{CFB} / \mathrm{CFC}$ ) and unit M3 (hosting shell-rich layer CI), correspond with mean accumulation rates of $\sim 0.12 \mathrm{~m} / \mathrm{ka}$ and $0.05 \mathrm{~m} / \mathrm{ka}$, respectively. unit M3 yields maximum accumulation rates of $0.09 \mathrm{~m} / \mathrm{ka}$ and $0.27 \mathrm{~m} /$ $\mathrm{ka}(68 \%$ and $95 \% \mathrm{CI}$, respectively). Maximum accumulation rates cannot be defined for unit M2 upper due to imprecise age constraints. At Pinnacle Point, layers with marine shells are dated to $\sim 162 \pm 12 \mathrm{ka}, 125 \pm 10 \mathrm{ka}$, and $126 \pm 10 \mathrm{ka}(14,57)$, but none of these are considered "true" (entirely clast supported) middens (9). Younger "true" midden layers (i.e., entirely clast-supported, anthropogenic shell deposits) at Pinnacle Point (PP13B) dated by OSL between $110 \pm 10 \mathrm{ka}$ and $91 \pm 10 \mathrm{ka}(57,58)$ range between $0.01 \mathrm{~m} / \mathrm{ka}$ and $0.04 \mathrm{~m} / \mathrm{ka}$ (longest and shortest duration at $68 \%$
CI). Other true shell middens of this antiquity, such as Klasies River Mouth, have produced inconsistent and conflicting ages $(15,59)$, but considering all dates from diverse techniques with variable precision, accuracy, and meaning Jerardino (ref. 60) estimated an accumulation rate of $\sim 0.3 \mathrm{~m} / \mathrm{ka}$ or less. Short intervals of rapid accumulation similar to the rates observed at YFT1 cannot be ruled out with the existing data; thus, more precise ages of shellmidden layers at these sites would aid comparisons of accumulation rates. While there is abundant evidence of marine resource use in Europe and North Africa in the Late Pleistocene (61, 62), true shell middens in these regions are significantly younger than YFT1, and for Neanderthals sites, estimated occupation intensities based on accumulation rates are lower than those at South African sites.

Conservative estimates thus indicate the YFT1 sequence accumulated at least twice as quickly as the next most rapidly accumulated MSA midden. However, the short accumulation interval at YFT1 and its accumulation rate are similar to those of middens known from South African LSA and Holocene examples precisely dated by ${ }^{14} \mathrm{C}$ methods $(63,64)$. Despite diverse composition and decreased size of food items in LSA middens, inferred LSA midden accumulation rates from a compilation by Jerardino (ref. 60 ) range from $\sim 0.3$ to $4 \mathrm{~m} / \mathrm{ka}$ (mean $\sim 1.2 \mathrm{~m} / \mathrm{ka}$, median

Table 2. Comparison of other MSA middens close to YFT1 in age, and their accumulation characteristics

\begin{tabular}{|c|c|c|c|c|}
\hline Site & Layers or midden thickness (m) & Age range $(\mathrm{ka}, 95 \% \mathrm{Cl})$ & $\begin{array}{l}\text { Accumulation } \\
\text { duration (ka) }\end{array}$ & Accumulation rate $(\mathrm{m} / \mathrm{ka})$ \\
\hline YFT1 & Entire midden $(3.8 \mathrm{~m})$ & 119.9 to 113.1 & $\begin{array}{c}2.3 \text { to } 6.8 \text { (mean and } 95 \% \\
\mathrm{Cl} \text {, respectively) }\end{array}$ & $\begin{array}{l}1.7 \text { to } 0.6(95 \% \mathrm{Cl} \text { and } \\
\text { mean, respectively) }\end{array}$ \\
\hline BBC & $\begin{array}{l}0.24 \mathrm{~m} \text { (unit M2 upper, for layer CFB/CFC) } \\
\text { and } 0.86 \mathrm{~m} \text { for unit M3 (for layer } \mathrm{Cl} \text { ) }\end{array}$ & $\begin{array}{l}76 \pm 6 \text { to } 74 \pm 6 \text { (unit M2 upper) } \\
98 \pm 10 \text { to } 82 \pm 8 \text { (unit M3) }\end{array}$ & $\begin{array}{l}2 \pm 4.2 \text { and } 16 \pm 6.4 \\
\text { respectively }\end{array}$ & $\begin{array}{c}0.12 \text { and } 0.05 \text {, respectively } \\
\text { (mean) }\end{array}$ \\
\hline KRM & Entire midden $(20 \mathrm{~m})$ & $\sim 101$ to 66 & 65 & 0.3 \\
\hline PP13B & $\begin{array}{l}\text { Upper roof spall and shelly brown sand } \\
\text { (est. } 0.4 \mathrm{~m} \text { ) }\end{array}$ & $\sim 115$ to 90 & 25 & 0.02 \\
\hline
\end{tabular}


$1 \mathrm{~m} / \mathrm{ka}$ ) encompassing the range estimated at YFT1. These rates are also similar to those of Holocene middens elsewhere, such as pre-Columbian middens in coastal California, for example (e.g., refs. 65 and 66), and LSA megamiddens in South Africa: massive open-air marine-shell accumulations of more than $1,000 \mathrm{~m}^{3}$ of material with accumulation rates of $\sim 0.5$ to $2 \mathrm{~m} / \mathrm{ka}(64,67)$. Considering such precise ages for an MSA midden reported herein, we suggest that midden accumulation rates may not have changed much between the YFT sequence and LSA middens. Moreover, the ages at YFT1 midden represent the earliest known evidence of intensive, systematic, recurrent occupation and resource use and thus the earliest evidence of a full coastal adaptation (cf. ref. 9) by humans.

Although YFT1 accumulation rates are similar to those of some LSA sites, important differences also stand out. For example, statistically significant differences among prey size at MSA versus LSA sites on the western and southern coasts of South Africa (Fig. 1) have been described, a relation interpreted to indicate resource depletion during the LSA resulting from increased LSA population size (10). A smaller population of MSA humans that systematically exploited marine resources may explain why the YFT1 sequence accumulated as rapidly as some LSA middens. That is, smaller populations of MSA people may have been able to forage at the same rate as LSA people, without depleting shellfish resources to the same extent. Smaller populations may also be able to forage as intensively but with fewer visits to the shore, allowing shellfish to attain larger sizes. This also agrees with other indications that MSA populations may have been smaller than those in the LSA (4).

A Cooling, Drying Climate Indicated by OES Stable Isotopes. Collectively, the stable carbon, nitrogen, and oxygen isotopes of OES can be used to reconstruct local paleoenvironments directly correlated to areas where humans subsisted. Furthermore, OES stable isotopic compositions provide local paleoenvironmental proxies relevant to the spatial scales $\left(<100 \mathrm{~km}^{2}\right)$ utilized by foraging humans (68). Since ostriches are mostly nonselective feeders who forage on green (leafy; hereafter foliar) plant material available within their daily home range $\left(\sim 85 \mathrm{~km}^{2}\right)(69,70)$, their diet provides a record of past local vegetation (e.g., refs. 28-30) at a similar spatial scale as human foraging. Comparison of individual OES isotopic compositions provide some indication of the variability of paleoenvironmental data recorded by OES in a very brief interval not resolvable by geochronology. Collectively, mean values provide an average and measure of variation (from the SD of the mean) of these variables. Mean stable-isotope values for OES from multiple fragments from each LG illuminate changes through time at the temporal resolution provided by the modeled ${ }^{230} \mathrm{Th} / \mathrm{U}$ ages. Hence, mean values encompass variation expected since individual OES fragments represent "snapshots" of paleoenvironmental variability at the seasonal timescale. For more details, reference SI Appendix, section 3.3.

Stable-isotope results were obtained from OES in LG 1 to LG 4, LG 6, and LG 8 to LG 12 and were assigned ages using the Bayesian age model. Individual analyses are plotted in Fig. 4 with means and $1 \sigma$ uncertainties for between 2 and 10 fragments per LG (SI Appendix). LG 6 is constrained by only two data points, and there is no data for directly bracketing layers, and thus mean values for this LG should be interpreted with caution. $\delta^{13} \mathrm{C}$ (versus Vienna Pee Dee Belemnite) values range from -15.59 to $-6.98 \%$, corresponding to $\delta^{13} \mathrm{C}_{\mathrm{diet}}$ values ranging from -31.79 to $-23.18 \%$ (Dataset S1 and SI Appendix, Table S2). These all fall within the range expected for $\mathrm{C}_{3}$ plant consumption, although contributions of $\mathrm{C}_{4}$ plants to the diet of up to $\sim 25 \%$ cannot be ruled out. These values thus imply a predominantly or entirely $\mathrm{C}_{3}$-plantrich diet. Dietary $\delta^{13} \mathrm{C}$ values reflecting a largely (or entirely) $\mathrm{C}_{3}$ landscape in the Western Cape are similar to modern vegetation dominated by diverse endemic fynbos ecosystems and $\mathrm{C}_{3}$ grasses (e.g., refs. 71 and 72), as well as relatively low growing season temperature (mean annual temperature $=16.6^{\circ} \mathrm{C}$ ) that is more hospitable to $\mathrm{C}_{3}$ vegetation in the winter rainfall zone (e.g., ref. 72). $\delta^{15} \mathrm{~N}$ values serve as a quantitative proxy for mean annual precipitation (MAP; refs. 29 and 30). We examined the fractionation between $\delta^{13} \mathrm{C}$ values from carbonate and organic fractions of OES $\left(\Delta^{14} \mathrm{C}_{\text {calcite-TOF }}=15 \pm 2 \%\right.$ ) to verify that the organic fractions have preserved primary isotopic compositions and so the $\delta^{15} \mathrm{~N}$ values can be reliably interpreted (refs. 29 and 30 and SI Appendix). The $\Delta^{14} \mathrm{C}_{\text {calcite-TOF }}$ exceeded the expected range in 4 of 40 samples, indicating the TOF had been altered, so these were left out of interpretations of the $\delta^{15} \mathrm{~N}$ values (SI $A p$ pendix). $\delta^{15} \mathrm{~N}$ values (versus AIR) in OES samples range from 6.4 to $12.4 \%$ at YFT1 (Dataset S1), indicating paleo-MAP values ranging from $\sim 200$ to $740 \mathrm{~mm} /$ year, respectively. These values are mostly higher than modern MAP of $\sim 350 \mathrm{~mm} /$ year. Varying $\delta^{18} \mathrm{O}$ values with time are mostly governed by changes in evapotranspiration of foliar water, which is controlled by changes in temperature, relative humidity, and/or photosynthetic performance, if the $\delta^{18} \mathrm{O}$ of meteoric source water is not changing; for full a explanation, see ref. 30. $\delta^{18} \mathrm{O}$ values (versus Vienna Standard Mean Ocean Water) range from 27.48 to $38.41 \%$, corresponding with $\delta^{18} \mathrm{O}_{\text {foliar values of }}-1.30$ to $6.18 \%$, respectively. Reference $S I$ Appendix for an explanation of these isotope proxies.

Mean $\delta^{13} \mathrm{C}_{\text {diet }}$ values range narrowly from -27.8 to $-25.7 \%$ (Table 3 and Fig. 4). With the exception of LG 6, which is constrained only by two data points, the consistency of mean $\delta^{13} \mathrm{C}_{\text {diet }}$ values is striking compared to the trends in the $\mathrm{N}$ and $\mathrm{O}$ stable-isotope records through time. Mean $\delta^{15} \mathrm{~N}$ values increased over time from $8.1 \%$ during LG 12 to $10.7 \%$ during LG $1 / 2$, corresponding to a decrease in paleo-MAP values from $590 \mathrm{~mm} /$ year to $350 \mathrm{~mm} /$ year that is equivalent to an $\sim 40 \%$ decrease in precipitation during the brief occupation interval. $t$ tests verify that mean $\delta^{15} \mathrm{~N}$ values are significantly different between the lowermost and uppermost LGs (SI Appendix and Dataset S1). This apparent shift agrees with other aridity proxy records supporting a period of extreme aridification in the winter rainfall zone between $\sim 120$ and $114 \mathrm{ka}(73,74)$. Mean $\delta^{18} \mathrm{O}$ values of OES tend to decrease significantly between LG 12 and LG 8, implying an overall decrease in evapotranspiration. LG 1 through LG 4 may either maintain this decreasing trend within errors, or they are similar to $\mathrm{LG} 8$, restricting significant changes in mean $\delta^{18} \mathrm{O}$ values to the lower half of the deposit. In either case, decreases in evapotranspiration generally correlate with the decreasing trend in mean values for paleo-MAP. Because the inferred diet did not change significantly through this interval, it is unlikely that changes in photosynthetic performance are controlling changes in the $\delta^{18} \mathrm{O}_{\text {foliar values. Since changes in evapotranspi- }}$ ration are otherwise controlled by changes in temperature and relative humidity (75), lower evapotranspiration indicates lower temperatures or higher relative humidity. It is counterintuitive to envision a regime in which lower precipitation would lead to higher relative humidity-rather, it is more likely that relative humidity would decrease with decreasing precipitation. Given that humidity is unlikely to increase during lower precipitation regimes, the observed decreases in $\delta^{18} \mathrm{O}_{\text {foliar values are likely due }}$ to decreased temperatures. Hence, increased $\delta^{18} \mathrm{O}$ values, coupled with higher paleo-MAP during earlier occupation intervals, likely indicate wetter, warmer environments, and intervals with lower paleo-MAP and evapotranspiration indicate drier and cooler environments during later occupation. Integration of the three isotope proxies indicate coincident decreases in precipitation and evapotranspiration driven by lower temperatures, with no significant changes to predominantly $\mathrm{C}_{3}$ local vegetation through time.

Using the Bayesian age-depth model and site stratigraphy, stable-isotope proxy records from OES resolve changes in the local paleoenvironment surrounding YFT1 by sampling OES in 

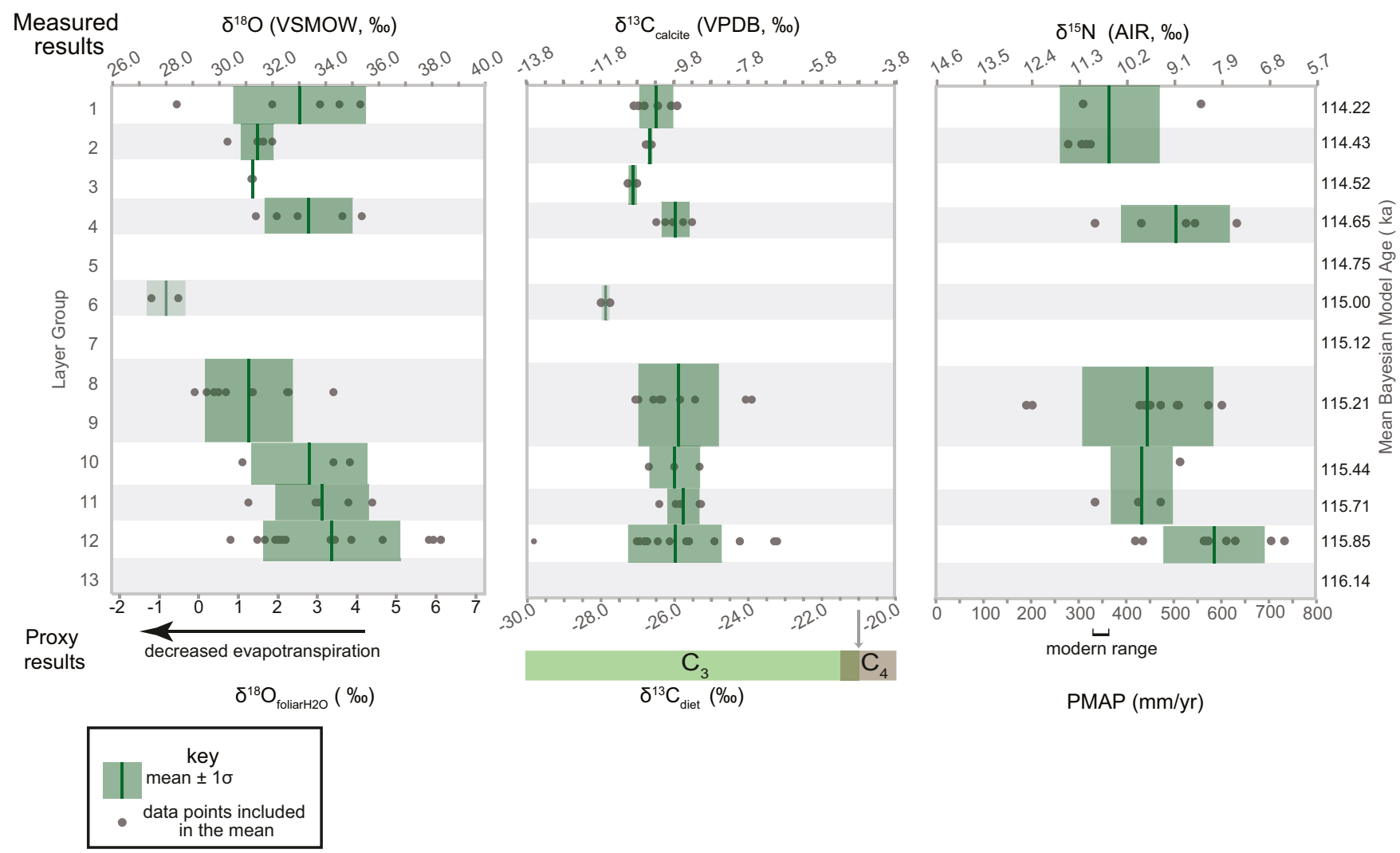

Fig. 4. Oxygen, carbon, and nitrogen isotope data for OES from YFT1. Horizontal axes show measured values (Upper) and corresponding proxy values (Lower). Vertical axes show stratigraphic LGs (Left) and mean Bayesian model ages (Right). Mean values (green blocks) are calculated for samples from each LG, showing environmental variability during human occupancy of YFT1. LG 6 is constrained by only two data points, and there is no data for directly bracketing layers and thus should be interpreted with caution. Note that $\delta^{15} \mathrm{~N}$ and $\delta^{18} \mathrm{O}$ values vary inversely, while $\delta^{13} \mathrm{C}$ values remain roughly constant throughout the occupation of YFT1, suggesting that decreasing evapotranspiration through time was driven by falling temperature.

each LG representing perhaps only centuries of time. Occupation of YFT1 occurred shortly after the LIG sea-level highstand, at a time when sea level was also rapidly decreasing. These proxy records support the climate being wettest (higher MAP and evapotranspiration) just after the LIG and becoming progressively drier and cooler into Marine Isotope Stage (MIS) 5d ( 123 to $109 \mathrm{ka}$; cf. ref. 76), supporting other interpretations that there was a cooler, drier climate in the region immediately following the LIG during the interval YFT1 was occupied $(73,74)$.

\section{Discussion}

Intensive Coastal Adaptations of a Fragmented Population. The marine shell-supported deposits in deeper LGs at YFT1, particularly LG 12 through LG 6 , meet the definition of a true shell midden and reflect the full expression of a coastal adaptation by humans (cf. ref. 9). While broader definitions of coastal adaptations may include any evidence of marine resource consumption that may increase reproductive fitness (e.g., ref. 61), the new OES ${ }^{230} \mathrm{Th} / \mathrm{U}$ burial ages imply YFT1 hosts the oldest known evidence of systematic,

Table 3. Mean isotope values and 1 $\sigma$ SD (green lines and bars in Fig. 4, respectively), with proxy values associated with each isotope system

\begin{tabular}{|c|c|c|c|c|c|c|c|c|c|c|c|c|c|c|}
\hline Layer & $\begin{array}{l}\text { Model age range } \\
\qquad(\mathrm{ka}, 95 \% \mathrm{Cl})\end{array}$ & $\begin{array}{l}\text { Model mean } \\
\text { age (ka) }\end{array}$ & $\begin{array}{c}\text { Mean } \\
\delta^{13} C_{\text {Calcite }}\end{array}$ & $\delta^{13} \mathrm{C}_{\text {Calcite }}^{ \pm}$ & $\begin{array}{l}\text { Mean } \\
\delta^{13} C_{\text {diet }}\end{array}$ & $\delta^{13} \mathrm{C}_{\text {diet }}^{ \pm}$ & $\begin{array}{c}\text { Mean } \\
\delta{ }^{18} O_{\text {Calcite }}\end{array}$ & $\delta^{18} \mathrm{O}_{\text {Calcite }}^{ \pm}$ & $\begin{array}{c}\text { Mean } \\
\delta^{18} \mathrm{O}_{\text {foliar }}\end{array}$ & $\delta^{18}{\stackrel{ \pm}{\mathrm{O}_{\text {foliar }}}}^{ \pm}$ & $\begin{array}{c}\text { Mean } \\
\delta{ }^{15} \mathrm{~N}_{\text {TOF }}\end{array}$ & $\delta^{15} \stackrel{ \pm}{\mathrm{N}}_{\mathrm{TOF}}$ & $\begin{array}{l}\text { Mean } \\
\text { PMAP }\end{array}$ & $\stackrel{ \pm}{ \pm}$ \\
\hline 1 & $115.9-112.9$ & 114.64 & -10.27 & 0.48 & -26.47 & 0.48 & 33.02 & 2.49 & 2.49 & 2.49 & 9.7 & 1.9 & 439 & 175 \\
\hline 2 & $116.0-113.6$ & 114.84 & -10.43 & 0.06 & -26.63 & 0.06 & 31.43 & 0.63 & 1.40 & 0.63 & 11.1 & 0.2 & 311 & 20 \\
\hline 3 & $116.2-113.7$ & 114.92 & -10.86 & 0.18 & -27.06 & 0.18 & 31.27 & 0.03 & 1.30 & 0.03 & - & - & - & - \\
\hline 4 & $116.3-113.8$ & 115.03 & -9.73 & 0.38 & -25.93 & 0.38 & 33.36 & 1.66 & 2.72 & 1.66 & 9.1 & 1.3 & 498 & 114 \\
\hline 5 & $116.5-113.9$ & 115.12 & - & - & - & - & - & - & - & - & - & - & - & - \\
\hline 6 & $116.8-114.1$ & 115.34 & -11.56 & 0.16 & -27.76 & 0.16 & 28.00 & 0.74 & -0.94 & 0.74 & - & - & - & - \\
\hline 7 & $117.0-114.2$ & 115.45 & - & - & - & - & - & - & - & - & - & - & - & - \\
\hline 8 and 9 & $117.1-114.3$ & 115.52 & -9.62 & 1.10 & -25.82 & 1.10 & 31.11 & 1.67 & 1.18 & 1.67 & 9.7 & 1.5 & 442 & 138 \\
\hline 10 & $117.6-114.3$ & 115.71 & -9.73 & 0.68 & -25.93 & 0.68 & 33.42 & 2.19 & 2.76 & 2.19 & 8.9 & 0.2 & 517 & 100 \\
\hline 11 & $117.9-114.5$ & 115.95 & -9.49 & 0.48 & -25.69 & 0.48 & 33.88 & 1.76 & 3.08 & 1.76 & 9.9 & 0.6 & 419 & 57 \\
\hline 12 & $118.3-114.6$ & 116.08 & -9.67 & 1.29 & -25.87 & 1.29 & 34.24 & 2.56 & 3.33 & 2.56 & 8.1 & 1.2 & 587 & 106 \\
\hline 13 & $119.6-114.6$ & 116.34 & - & - & - & - & - & - & - & - & - & - & - & - \\
\hline
\end{tabular}

All individual stable-isotope data points can be found in Dataset S1. PMAP = paleo-mean annual precipitation. 
recurrent shellfishing in southern Africa or elsewhere. Only one other site provides possibly contemporaneous evidence of intensive marine shellfishing by humans as evidenced by a "true" midden deposit-Klasies River Mouth—but the age of the older MSA 1 layers at this site is only broadly constrained to $\sim 110 \mathrm{ka}$ by a maximum age constraint for underlying deposits (15). The rapid accumulation of the YFT1 sequence indicates the relatively high intensity of site occupancy, akin to that implied by some LSA sites, and consistent with fully developed coastal foraging behavior in which exploitation of marine resources has become a sustained and substantial activity.

The Bayesian age model results (Fig. 3) provide constraints on other notable finds in the YFT1 record. The model constrains the age of the isolated human teeth from LG 4 and LG 5 to 115.8 to $113.9 \mathrm{ka}$ and 116.2 to $113.9 \mathrm{ka}(95 \% \mathrm{CI})$, respectively. A minimum age for the isolated tooth from LG 13 is constrained by the minimum age of LG 13 at $95 \%$ CI (114.5 ka), but because it may have been reworked, it may predate the storm-surge deposits in LG 13. These teeth are interpreted as being within the range of variation for modern $H$. sapiens (38), placing them among the oldest examples of $H$. sapiens in southern Africa, contemporaneous with the broad age constraints for some dentitions at Klasies River Mouth (c. 110 to $90 \mathrm{ka})(2,15,59)$. While the YFT1 lithic technocomplex is similar to other MSA assemblages found at west coast sites lacking precise ages, such as Hoedjiespunt, Sea Harvest, and Die Kelders (Fig. 1), it has been described as distinct from the MSA1 levels of similar age at Klasies River Mouth on the southern coast, also associated with shell-rich deposits (77). Our age constraints indicate the diachronous and earlier occurrence of the YFT1 technology compared to more widespread technocomplexes like the Still Bay (SB, $\sim 76$ to $67 \mathrm{ka})(78,79)$ and Howiesons Poort industries (HP, $\sim 65$ to $59 \mathrm{ka})(80)$, coherent technocomplexes that are present over large regions of southern Africa during MIS 4 ( 71 to $57 \mathrm{ka})$ (e.g., refs. 78 and 80 ). The earliest evidence of the SB industry appears during the transition from MIS 5 to 4 and appears in both the western and southern African coastal archaeological record, when climates inland of the western coast are interpreted to have become wetter and warmer, and the winter rainfall zone is thought to have expanded landward and along the southern coast into today's year-round rainfall zone (cf. Fig. 1; e.g., ref. 81). During occupation of YFT1, distinct but concurrent lithic technologies imply that populations may have been more isolated (or fragmented; e.g., ref. 82). The appearance of the SB technologies reflects longer-range human interactions (or coalescing populations; ref. 82) spanning coastal and terrestrial regions in the winter rainfall zone during MIS 4.

With the ages presented here, we can assess the position of the YFT1 shelter relative to the shoreline and assess the influence of shoreline distance on foraging strategies. To conservatively estimate the distance from YFT1 to the shoreline during its occupation, we use a global composite sea-level curve (33), which broadly represents the changing shoreline during the occupation interval. The estimated sea-level curve indicates that YFT1 is expected to have been above sea level during its newly dated occupation interval (Fig. 5). Mean ages from OSL-dated local paleo-shoreline deposits put southern African coastal deposits closer to the upper 95\% CI limit of global mean RSL curves (black dotted lines in Fig. 5) and particularly marine transgressions, occurring during MIS 5e (32). For a more conservative estimate of the distance of YFT1 to the shore, we refer to the lower extreme of sea-level change at $95 \%$ CI. The lowest estimated sea level during occupation of YFT1 was -50 m RSL, just before YFT1 was abandoned. Sea level underwent drastic changes during the Late Pleistocene, decreasing by as much $\sim-57$ mRSL around YFT1 during its occupation. Pairing sea-level models with modern proximal ocean bathymetry (after ref. 83; Fig. 5), a depth of -50 mRSL by shelter abandonment at $\sim 112.9 \mathrm{ka}$ corresponds with a distance of $\sim 3 \mathrm{~km}$ between YFT1 and the paleo shoreline, which is well within the maximum foraging distance of $\sim 5$ to $10 \mathrm{~km}$ determined from studies of modern and recent foragers (e.g., refs. 68 and 84).

Despite clear changes in terrestrial climate and sea level during occupation of YFT1, there are not major changes in the amount and proportions of different shellfish species through time in the YFT1 sequence. Relatively constant ratios between black mussels (Choromytilus meridionalis) to limpets, and between relative abundances of the three most common limpets, Patella (Cymbula) granatina, Patella (Scutellastra) granularis, and Patella (Scutellastra) argenvillei, were previously interpreted to indicate a stable marine ecosystem and, by inference, a relatively stable sea level (12). However, the data indicate that YFT1 was occupied during a period of rapidly falling sea level, showing that its occupants were, nevertheless, able to access shellfish within reasonable foraging distances, despite large declines in sea level. It implies occupants were carefully tracking tidal cycles to target specific food sources only safely available during $~$ bimonthly low spring tides, such as $P$. argenvillei. South African coastal sites, which combine rich marine and terrestrial resources, have been hypothesized to be possible refugia in periods of unfavorable environmental conditions in Africa's interior (e.g., refs. 8, 84 and 85). At YFT1, humans were at least able to sustain food resources during a transition to a less hospitable climate.

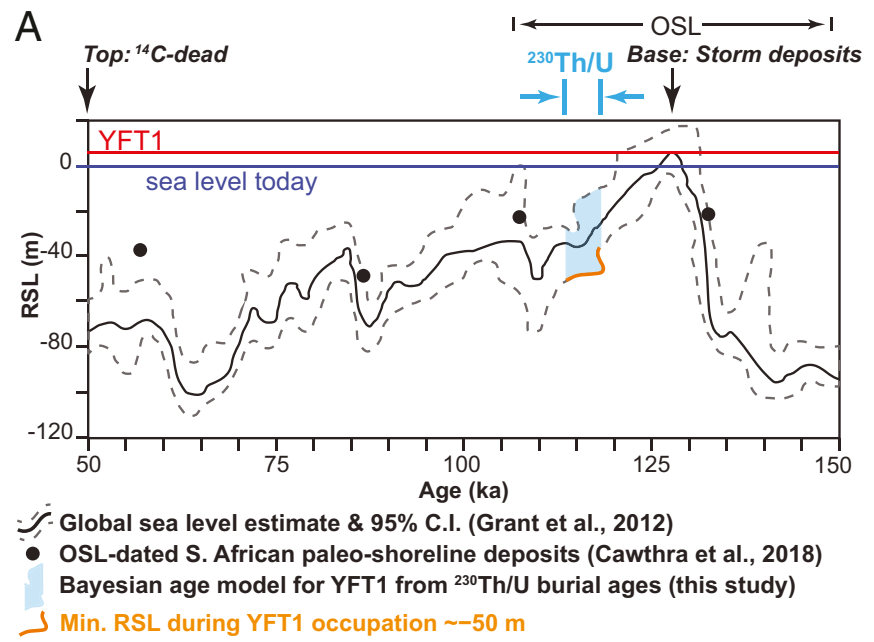

B

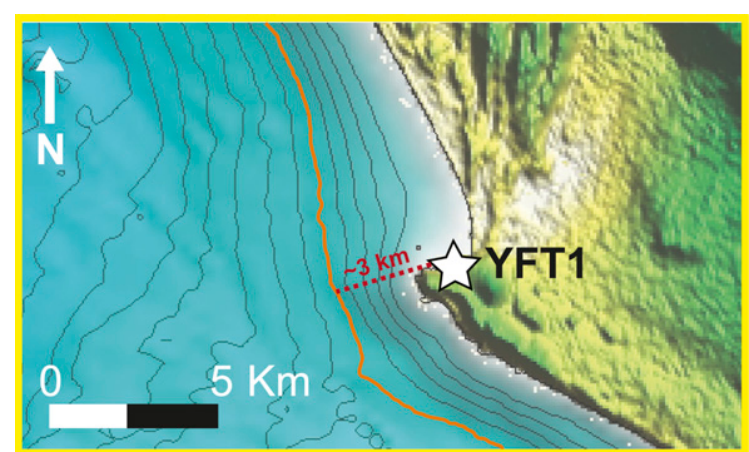

Fig. 5. (A) ${ }^{230} \mathrm{Th} / \mathrm{U}$ burial ages refine prior chronological constraints. YFT1 relative to changing sea level $(32,33)$ during its occupation $\sim 120$ to $113 \mathrm{ka}$ implies sea up to $-50 \mathrm{~m}$, or $-57 \mathrm{~m}$ relative to the base of YFT1. Storm-surge deposits likely date to the LIG sea-level highstand. $(B)$ Using sea-level estimates, offshore bathymetry (modified after ref. 83 ) highlighting $10 \mathrm{~m}$ isobaths (gray lines) implies the shoreline may have been $\sim 3 \mathrm{~km}$ away at -50 $\mathrm{mRSL}$ (orange isobath), within range of typical distances foragers are willing to travel for resources $(68,84)$. 
The shelter may have been abandoned when it was too far from the shore for shellfishing to remain efficient. If coastal foragers moved seaward to accommodate the changing coastline, either before or after occupation of YFT1, evidence of those occupations would be under water today, suggesting that preservation of coastal shelters may be biased by geological processes, preserving only those not washed out by the LIG sea-level highstand during MIS 5e (e.g., refs. 32-34 and 50). Only one site on the southern African coastline is known to have well-dated marine shell-bearing deposits older than the MIS 5e highstand, those at Pinnacle Point, which yield luminescence ages as old as $\sim 166 \mathrm{ka}$, are located up to $\sim 15 \mathrm{mRSL}$, and would have been $\sim 4$ to $8 \mathrm{~km}$ from the contemporary shoreline during a brief interval at about that time $(9,14)$. There may be other shell middens older than YFT1 along these coastlines above water, corresponding with older highstands-particularly just before and during MIS 7, between 250 to $190 \mathrm{ka}(74,76,86)$-and it may now be possible to date them with ${ }^{230} \mathrm{Th} / \mathrm{U}$ burial dating of OES.

\section{Conclusions}

Using a recently developed approach to ${ }^{230} \mathrm{Th} / \mathrm{U}$ dating of OES, we have obtained $11^{230} \mathrm{Th} / \mathrm{U}$ burial ages for the MSA shell midden at YFT1. Burial ages have a median error of $3.1 \mathrm{ka}(2 \sigma)$, multiple ages from dated LGs are in mutual agreement, and the ages preserve stratigraphic order within errors. U-concentration profile patterns of OES from YFT1 are self-consistent, and tightly clustered ${ }^{230} \mathrm{Th} / \mathrm{U}$ burial ages preserve stratigraphic principles, host features consistent with early initiation of $U$ uptake upon burial, and agree with other chronological constraints. A Bayesian age model provides dates for human occupation at YFT1 from 119.9 to $113.1 \mathrm{ka}(95 \% \mathrm{CI})$ closely following the sea-level highstands of the Last Interglaciation (circa 127 and $120 \mathrm{ka}$ ) and indicating deposition of the $\sim 3.8 \mathrm{~m}$ sequence in circa 2 to $7 \mathrm{ka}$. The ages make YFT1 the oldest well-dated true shell midden and show that it was intensively occupied during a brief period of rapidly falling sea level.

Analyses of $\mathrm{C}, \mathrm{N}$, and $\mathrm{O}$ stable isotopes of OES provide insight into terrestrial conditions in the vicinity of the YFT1 site. While $\delta^{13} C_{\text {diet }}$ values remain roughly constant and indicative of a $C_{3}$-rich flora, $\delta^{15} \mathrm{~N}$ values indicate MAP decreased during site occupation from about $\sim 600 \mathrm{~mm} / \mathrm{yr}$ to $\sim 350 \mathrm{~mm} / \mathrm{yr}$, with the latter approaching the modern value. Based on coincident changes in $\delta^{15} \mathrm{~N}$ and $\delta^{18} \mathrm{O}$ values, we infer that paleo-MAP decreased with evapotranspiration through time. Paired with insights from $\delta^{13} \mathrm{C}$ values, $\delta^{18} \mathrm{O}$ values indicate decreasing temperatures during site occupation, and altogether, the isotope proxies support interpretations of a cooler and drier climate relative to LIG conditions in the winter rainfall zone of southern Africa during this interval. However, the inferred rapid changes in climate, environment, and sea level did not noticeably impact the composition of the faunal record at YFT1, indicating that the YFT1 occupants were able to compensate for those changes with adaptive foraging strategies in order to maintain their preferred diet.

The ages provide constraints on some of the oldest fossil material of $H$. sapiens in southern Africa. Furthermore, they show that the extensive lithic-artifact collection from YFT1 predates the well-known SB and HP industries by c. $35 \mathrm{ka}$ at most sites (cf. ref. 80). Unlike those widespread industries, YFT1 lithic artifacts are

1. C. S. Henshilwood et al., The origin of modern human behavior: Critique of the models and their test tmplications. Curr. Anthropol. 44, 627-651 (2003).

2. F. E. Grine, R. G. Klein, T. P. Volman, Dating, archaeology and human fossils from the middle stone age levels of Die Kelders, South Africa. J. Hum. Evol. 21, 363-395 (1991).

3. R. G. Klein, Out of Africa and the evolution of human behavior. Evol. Anthropol. 17, 267-281 (2008).

4. R. G. Klein, D. W. Bird, Shellfishing and human evolution. J. Anthropol. Archaeol. 44 198-205 (2016)

5. J. E. Parkington, "Coastal diet, encephalization, and innovative behaviors in the late Middle Stone Age of southern Africa" in Human Brain Evolution: The Influcence of Freshwater and Marine Food Resources, S. C. Cunnane, K. M. Stewart, Eds. (WileyBlackwell, 2010), pp. 189-202. distinct from potentially coeval industries at other MIS 5 sites, consistent with less technological exchange in MIS 5 and more isolated human population groups.

The accumulation rate at YFT1 is similar to some LSA sites, challenging previous concepts of less-intensive site occupancy in the MSA. This indicates that MSA humans were intensively exploiting local marine resources by c. $120 \mathrm{ka}$, providing a nutritious, sustainable food source along the coast that was insulated from potentially less-hospitable terrestrial climate regimes. Consequentially, coastal environments may have provided stable habitats during climatic changes, serving as potential refugia, and incentivizing low-mobility, denser localized populations and potential territoriality to protect coastal food sources (cf. refs. 8 and 9). High-resolution temporal and paleoenvironmental placement of YFT1 provides insight into trends of foraging strategies, intergroup communication, and technological exchange by humans in the MSA, and this record demonstrates that humans were systematic, adaptive foragers by early MIS 5 , with a distinct lithic industry that may be unique to the west coast region.

\section{Materials and Methods}

OES samples were selected from curated collections housed at the Iziko Mu seums of South Africa in Cape Town, and they were assigned Berkeley Geochronology Center (BGC) laboratory numbers (Dataset S1). For LA analyses, each OES fragment was cut to expose the cross-section of the eggshell on a fresh surface, mounted in epoxy, and polished (SI Appendix, Figs. S1-S5). Insitu concentrations of ${ }^{238} \mathrm{U}$ and ${ }^{232} \mathrm{Th}$ in eggshell samples were evaluated via LA using a Photon Machines Analyte II excimer laser attached to a ThermoFisher NEPTUNE Plus ICP-MS. Subsamples from palisade-layer crystals of eggshells were prepared for U-series geochronology using a Dremel hand tool, totally dissolved in $7 \mathrm{~N} \mathrm{HNO}_{3}$, equilibrated with a mixed spike containing ${ }^{229} \mathrm{Th}$, ${ }^{233} U$, and ${ }^{236} U$, and $U$ and Th were separated from sample matrix using two stages of $\mathrm{HNO}_{3}-\mathrm{HCl}$ cation exchange chemistry followed by reaction with $\mathrm{HNO}_{3}$ and $\mathrm{HClO}_{4}$ to remove any residual organic material. OES subsamples were dated in BGC's U-Daughter Lab via solution analyses with an Aridus II desolvator and the Neptune Plus ICP-MS. For stable isotope analyses, after removal of weathered surfaces and pores in subsamples weighing 2300 to $400 \mathrm{mg}, 20$ to $30 \mathrm{wt} \%$ of the OES is leached in $1 \mathrm{~N} \mathrm{HCl}$. An $\sim$ submg-sized sample is drilled out in cross-section of the leached OES fragment for calcite analyses, while the remaining leached fragment is dissolved in $1 \mathrm{~N} \mathrm{HCl}$ for organic analyses. Isotopic analyses were completed in the University of California Berkeley Center for Stable Isotope Biogeochemistry. Stable isotope abundances are reported in delta $(\delta)$ notation in parts per thousand (\%o) where: $\delta=\left(\left(R_{A} / R_{S}\right)-1\right) \times 1,000$, where $R_{A}$ and $R_{S}$ are the ratios of the rare to abundant in the sample of interest and in an international standard, respec tively. For comprehensive methods, reference SI Appendix.

Data Availability. All study data are included in the article and/or supporting information

ACKNOWLEDGMENTS. We thank the Leakey Foundation and the Ann and Gordon Getty Foundation for support. This research is based in part on work supported by the NSF under Grant No. BCS-1727085 to W.D.S. and C.A. Tryon. We thank Richard Klein for his effort to recover and curate the materials studied here, for requesting sample export permits, and for constructive discussions of the results of this work. We thank Zenobia Jacobs for discussion of her OSL data. We thank South African Heritage Resources Agency (SAHRIS) and Heritage Western Cape for permits (SAHRIS CaseID 9905 and Permit ID 2380); Iziko Museums for curation of the YFT1 material; Luis Erick Aguirre Palafox for sample preparation assistance; Christina Polito and Brian Jones for help with ${ }^{230} \mathrm{Th} / \mathrm{U}$ analyses; and Stefania Mambelli and Wenbo Yang for directing stable isotope analyses.

6. K. Kyriacou, D. M. Blackhurst, J. E. Parkington, A. D. Marais, Marine and terrestrial foods as a source of brain-selective nutrients for early modern humans in the southwestern Cape, South Africa. J. Hum. Evol. 97, 86-96 (2016).

7. S. Cunnane, "Human brain evolution: A question of solving key nutritional and metabolic constraints on mammalian brain development" in Human Brain Evolution: The Influence of Freshwater and Marine Food Resources, S. C. Cunnane, K. M. Stewart, Eds. (Wiley-Blackwell, 2010), pp. 33-64.

8. C. W. Marean, "Coastal South Africa and the coevolution of the modern human lineage and the coastal adaptation" in Trekking the Shore: Changing Coastlines and the Antiquity of Coastal Settlement, N. F. Bicho, Ed. (Springer, 2011), pp. 421-440.

9. C. W. Marean, The origins and significance of coastal resource use in Africa and Western Eurasia. J. Hum. Evol. 77, 17-40 (2014). 
10. R. G. Klein et al., The Ysterfontein 1 Middle Stone Age site, South Africa, and early human exploitation of coastal resources. Proc. Natl. Acad. Sci. U.S.A. 101, 5708-5715 (2004).

11. R. G. Klein, T. E. Steele, Archaeological shellfish size and later human evolution in Africa. Proc. Natl. Acad. Sci. U.S.A. 110, 10910-10915 (2013)

12. G. Avery et al., The Ysterfontein 1 middle stone age rock shelter and the evolution of coastal foraging. Goodwin Ser. 10, 66-89 (2008).

13. D. Halkett et al., First excavation of intact middle stone age layers at Ysterfontein, western cape Province, South Africa: Implications for middle stone age ecology. J. Archaeol. Sci. 30, 955-971 (2003).

14. C. W. Marean et al., Early human use of marine resources and pigment in South Africa during the Middle Pleistocene. Nature 449, 905-908 (2007).

15. F. E. Grine, S. Wurz, C. W. Marean, The middle stone age human fossil record from Klasies River main site. J. Hum. Evol. 103, 53-78 (2017).

16. F. E. Grine, R. G. Klein, Late pleistocene human remains from the sea harvest site Saldanha bay, South Africa. S. Afr. J. Sci. 89, 145-152 (1993).

17. K. Kyriacou, J. E. Parkington, M. Will, A. W. Kandel, N. J. Conard, Middle and later stone age shellfish exploitation strategies and coastal foraging at Hoedjiespunt and Lynch point, Saldanha bay, SouthAfrica. J. Archaeol. Sci. 57, 197-206 (2015).

18. C. S. Henshilwood et al., Klipdrift Shelter, southern cape, South Africa: Preliminary report on the howiesons poort layers. J. Archaeol. Sci. 45, 284-303 (2014).

19. C. S. Henshilwood et al., A 100,000-year-old ochre-processing workshop at Blombos Cave, South Africa. Science 334, 219-222 (2011)

20. T. P. Volman, Early archeological evidence for shellfish collecting. Science 201 911-913 (1978)

21. J. Parkington, J.-Ph. Rigaud, C. Poggenpoel, G. Porraz, P.-J. Texier, Introduction to the project and excavation of Diepkloof Rock Shelter (Western Cape, South Africa): A view on the Middle Stone Age. J. Archaeol. Sci. 40, 3369-3375 (2013).

22. K. R. Ludwig, P. R. Renne, Geochronology on the paleoanthropological time scale Evol. Anthropol. 9, 101-110 (2000).

23. W. D. Sharp et al., ${ }^{230} \mathrm{Th} / \mathrm{U}$ burial dating of ostrich eggshell. Quat. Sci. Rev. 219, 362-276 (2019)

24. W. Sharp, N. D. Fylstra, C. A. Tryon, J. T. Faith, D. J. Peppe, U-Th burial dating of ostrich eggshell: A new geochronometer for African archaeological sites. Quat. Int. 404, 198-199 (2016)

25. E. M. Niespolo et al., "Patterns of Secondary U in ostrich Eggshell: Applicaiton to U-Th dating of Quaternay terrestrial Strata" (Geochemical Society, 2017).

26. E. M. Niespolo et al., "U-Th burial dating of ostrich eggshells: A novel approach to dating African archaeological sequences beyond the $14 \mathrm{C}$ limit" in GSA Annual Meeting (Geological Society of America, 2017).

27. W. D. Sharp, N. D. Fylstra, J. T. Faith, D. J. Peppe, C. A. Tryon, "U-series dating of ostrich eggshell" in Goldschmidt 2014 (Goldschmidt, 2014), p. 2265.

28. Y. Von Schirnding, N. J. Van der Merwe, J. C. Vogel, Influence of diet and age on carbon isotope ratios in ostrich eggshell. Archaeometry 24, 3-20 (1982).

29. B. J. Johnson, M. L. Fogel, G. H. Miller, Stable isotopes in modern ostrich eggshell: A calibration for paleoenviromental applications in semi-arid regions of southern africa. Geochim. Cosmochim. Acta 62, 2451-2461 (1998).

30. E. M. Niespolo et al., Carbon, nitrogen, and oxygen isotopes of ostrich eggshells provide site-scale Pleistocene-Holocene paleoenvironmental records for eastern African archaeological sites. Quat. Sci. Rev. 230, 106142 (2020).

31. B. J. Johnson, G. H. Miller, M. L. Fogel, P. B. Beaumont, The determination of late Quaternary palaeoenvironments at Equus Cave, South Africa, using stable isotopes and amino acid racemization in ostrich eggshell. Palaeogeogr. Palaeoclimatol. Palaeoecol. 136, 121-137 (1997).

32. H. C. Cawthra et al., Depositional and sea-level history from MIS 6 (Termination II) to MIS 3 on the southern continental shelf of South Africa. Quat. Sci. Rev. 181, 156-172 (2018)

33. K. M. Grant et al., Rapid coupling between ice volume and polar temperature over the past 150,000 years. Nature 491, 744-747 (2012).

34. A. S. Carr et al., The last interglacial sea-level high stand on the southern Cape coastline of South Africa. Quat. Res. 73, 351-363 (2010).

35. R. J. Dunham, "Classification of carbonate rocks according to depositional texture" in Classification of Carbonate Rocks: American Association of Petroleum Geol ogists Memoir (American Association of Petroleum Geologists, 1962), pp. 108-121.

36. A. F. Embry, J. E. Klovan, A late Devonian tract on Northeastern Banks island, NWT. Can. Pet. Geol. Bull. 19, 730-781 (1971)

37. S. Wurz, The significance of MIS 5 shell middens on the cape coast: A lithic perspective from Klasies River and Ysterfontein 1. Quat. Int. 270, 61-69 (2012).

38. C. Verna, J.-J. Hublin, T. E. Steele, Middle Stone Age human remains from the site of Ysterfontein 1 (South Africa). https://www.tahfr.cnrs.fr/wp-content/uploads/2014/09/ TAHFR_posters_list.pdf. Accessed 2 April 2020.

39. E. N. Wilmsen, Ostrich eggshells and their beads. S. Afr. Archaeol. Bull. 70, 89-105 (2015)

40. P. J. Texier et al., The context, form and significance of the MSA engraved ostrich eggshell collection from Diepkloof Rock Shelter, Western Cape, South Africa. J. Archaeol. Sci. 40, 3412-3431 (2013).

41. J. E. Parkington, C. Poggenpoel, P. Rigaud, P. J. Texier, "From tool to symbol: The behavioural context of intentionally marked ostrich eggshell from Diepkloof, Western Cape" in From Tools to Symbols-From Early Hominids to Modern Humans (Wits University Press, 2005), pp. 475-492.

42. A. S. Brooks et al., Dating pleistocene archeological sites by protein diagenesis in ostrich eggshell. Science 248,60-64 (1990).
43. G. H. Miller, M. L. Fogel, J. W. Magee, M. K. Gagan, Disentangling the impacts of climate and human colonization on the flora and fauna of the Australian arid zone over the past $100 \mathrm{ka}$ using stable isotopes in avian eggshell. Quat. Sci. Rev. 151, 27-57 (2016)

44. R. L. Edwards, J. H. Chen, T.-L. Ku, G. J. Wasserburg, Precise timing of the last interglacial period from mass spectrometric determination of thorium-230 in corals. Science 236, 1547-1553 (1987)

45. S. L. Loewy et al., Improved accuracy of U-series and radiocarbon dating of ostrich eggshell using a sample preparation method based on microstructure and geochemistry: A study from the middle stone age of Northwestern Ethiopia. Quat. Sci. Rev. 247, 106525 (2020).

46. A. H. Jaffey, K. F. Flynn, L. E. Glendenin, W. C. Bentley, A. M. Essling, Precision measurement of half-lives and specific activities of U235 and U238. Phys. Rev. C Nucl. Phys. 4, 1889-1906 (1971)

47. H. Cheng et al., Improvements in ${ }^{230} \mathrm{Th}$ dating, ${ }^{230} \mathrm{Th}$ and ${ }^{234} \mathrm{U}$ half-life values, and $\mathrm{U}$-Th isotopic measurements by multi-collector inductively coupled plasma mass spectrometry. Earth Planet. Sci. Lett. 371-372, 82-91 (2013).

48. K. R. Ludwig, J. B. Paces, Uranium-series dating of pedogenic silica and carbonate, Crater Flat, Nevada. Geochim. Cosmochim. Acta 66, 487-506 (2002).

49. M. J. Kohn, Models of diffusion-limited uptake of trace elements in fossils and rates of fossilization. Geochim. Cosmochim. Acta 72, 3758-3770 (2008).

50. M. J. O'Leary et al., Ice sheet collapse following a prolonged period of stable sea level during the last interglacial. Nat. Geosci. 6, 796-800 (2013).

51. A. C. Parnell, J. Haslett, J. R. M. Allen, C. E. Buck, B. Huntley, A flexible approach to assessing synchroneity of past events using Bayesian reconstructions of sedimentation history. Quat. Sci. Rev. 27, 1872-1885 (2008).

52. A. C. Parnell, C. E. Buck, T. K. Doan, A review of statistical chronology models for highresolution, proxy-based Holocene palaeoenvironmental reconstruction. Quat. Sci. Rev. 30, 2948-2960 (2011)

53. J. Haslett, A. Parnell, A simple monotone process with application to radiocarbondated depth chronologies. J. R. Stat. Soc. Ser. C Appl. Stat. 57, 399-418 (2008).

54. R Core Team, R: A Language and Environment for Statistical Computing. https://www. r-project.org/. Accessed 11 December 2018.

55. Z. Jacobs, B. G. Jones, H. C. Cawthra, C. S. Henshilwood, R. G. Roberts, The chronological, sedimentary and environmental context for the archaeological deposits at Blombos Cave, South Africa. Quat. Sci. Rev. 235, 105850 (2019).

56. M. M. Haaland et al., Geoarchaeological investigation of occupation deposits in Blombos Cave in South Africa indicate changes in site use and settlement dynamics in the southern Cape during MIS 5b-4. Quat. Res. 1-54 (2020)

57. Z. Jacobs, An OSL chronology for the sedimentary deposits from Pinnacle Point Cave 13B--A punctuated presence. J. Hum. Evol. 59, 289-305 (2010).

58. P. Karkanas, P. Goldberg, Site formation processes at Pinnacle point Cave 13B (Mossel bay, western cape Province, South Africa): Resolving stratigraphic and depositional complexities with micromorphology. J. Hum. Evol. 59, 256-273 (2010).

59. J. K. Feathers, Luminescence dating in less than ideal conditions: Case studies from Klasies River main site and Duinefontein, South Africa. J. Archaeol. Sci. 29, 177-194 (2002)

60. A. Jerardino, On the origins and significance of Pleistocene coastal resource use in southern Africa with particular reference to shellfish gathering. J. Anthropol. Archaeol. 41, 213-230 (2016).

61. M. Will, A. W. Kandel, N. J. Conard, Midden or molehill: The role of coastal adaptations in human evolution and dispersal. J. World Prehistory 32, 33-72 (2019).

62. T. E. Steele, "Late Pleistocene human subsistence in northern Africa: The state of our knowledge and placement in a continental context" in Modern Origins: A North African Perspective, J. J. Hublin, S. P. McPherron, Eds. (Springer, 2012), pp. 107-125.

63. A. Jerardino, R. Yates, Preliminary results from excavations at Steenbokfontein Cave: Implications for past and future research. S. Afr. Archaeol. Bull. 51, 7 (1996).

64. A. Jerardino, Megamiddens. Digging Stick 29, 12-16 (2012)

65. J. M. Erlandson, T. C. Rick, R. L. Vellanoweth, D. J. Kennett, Maritime subsistence at a 9300 year old shell midden on santa rosa island, California. Int. J. Phytoremediation 21, 255-265 (1999)

66. J. M. Erlandson, K. M. Gill, T. C. Rick, L. A. Reeder-Myers, Three late paleocoastal shell middens on santa cruz island, California. PaleoAmerica 1, 113-115 (2015).

67. A. Jerardino, R. Navarro, Large-scale hunter-gatherer exploitation of marine resources in South Africa, Part II: Grootrif and malkoppan megamiddens, lamberts bay area. S. Afr. Archaeol. Bull. 73, 108-125 (2018).

68. R. L. Kelly, The Lifeways of Hunter-Gatherers: The Foraging Spectrum (Cambridge University Press, 2013).

69. S. J. Milton, R. J. Dean, W. R. Siegfried, Food selection by ostrich in southern Africa. J. Wildl. Manage. 58, 234-248 (1994)

70. J. B. Williams et al., Field Metabolism, water requirements, and foraging behavior of wild ostriches in the Namib. Ecology 74, 390-404 (1993)

71. J. Schnitzler et al., Causes of plant diversification in the Cape biodiversity hotspot of South Africa. Syst. Biol. 60, 343-357 (2011).

72. J. C. Vogel, A. Fuls, R. P. Elliz, The distribution of Cranz grasses in South Africa. S. Afr. J. Sci. 74, 209-215 (1978).

73. J. B. W. Stuut, F. Lamy, Climate variability at the southern boundaries of the Namib (southwestern Africa) and Atacama (northern Chile) coastal deserts during the last 120,000 yr. Quat. Res. 62, 301-309 (2004).

74. J. B. W. Stuut et al., A 300-kyr record of aridity and wind strength in southwestern Africa: Inferences from grain-size distributions of sediments on Walvis Ridge, SE Atlantic. Mar. Geol. 180, 221-233 (2002).

75. A. Kahmen et al., Cellulose $(\delta)^{18} \mathrm{O}$ is an index of leaf-to-air vapor pressure difference (VPD) in tropical plants. Proc. Natl. Acad. Sci. U.S.A. 108, 1981-1986 (2011). 
76. L. E. Lisiecki, M. E. Raymo, A Pliocene-Pleistocene stack of 57 globally distributed benthic $\delta 180$ records. Paleoceanography 20, 1-17 (2005).

77. S. Wurz, The significance of MIS 5 shell middens on the cape coast: A lithic perspective from Klasies River and Ysterfontein 1. Quat. Int. 270, 61-69 (2012).

78. Z. Jacobs, R. G. Roberts, Single-grain OSL chronologies for the Still Bay and Howieson's Poort industries and the transition between them: Further analyses and statistical modelling. J. Hum. Evol. 107, 1-13 (2017).

79. Z. Jacobs, E. H. Hayes, R. G. Roberts, R. F. Galbraith, C. S. Henshilwood, An im proved OSL chronology for the Still Bay layers at Blombos Cave, South Africa: Further tests of single-grain dating procedures and a re-evaluation of the timing of the Still Bay industry across southern Africa. J. Archaeol. Sci. 40, 579-594 (2013).

80. Z. Jacobs et al., Ages for the middle stone age of Southern Africa: Implications for human behavior and dispersal. Science 322, 733-735 (2008).
81. B. M. Chase, M. E. Meadows, Late Quaternary dynamics of southern Africa's winte rainfall zone. Earth Sci. Rev. 84, 103-138 (2007).

82. A. Mackay, B. A. Stewart, B. M. Chase, Coalescence and fragmentation in the late Pleistocene archaeology of southernmost Africa. J. Hum. Evol. 72, 26-51 (2014)

83. W. M. de Wet, "Bathymetry of the South African continental shelf," Master's thesis, University of Cape Town, Cape Town, South Africa (2012).

84. J. M. Erlandson, The archaeology of aquatic adaptations: Paradigms for a new millennium. J. Archaeol. Res. 9, 287-350 (2001).

85. S. Wurz, Technological trends in the middle stone age of South Africa between MIS 7 and MIS 3. Curr. Anthropol. 54, S8 (2013).

86. J. C. Kraft, D. F. Belknap, I. Kayan, "Potentials of discovery of human occupation sites on the continental shelves and nearshore coastal zone" in Quaternary Coastlines and Marine Archaeology, P. M. Masters, N. C. Flemming, Eds. (Academic Press, 1983), pp. 87-120. 